\title{
International Space Station Atmosphere Control and Supply, Atmosphere Revitalization, and Water Recovery and Management Subsystem - Verification for Node 1
}

\author{
David E. Williams \\ NASA, Johnson Space Center
}

Copyright $@ 2007$ SAE International

\begin{abstract}
The International Space Station (ISS) Node 1 Environmental Control and Life Support (ECLS) System is comprised of five subsystems: Atmosphere Control and Supply (ACS), Atmosphere Revitalization (AR), Fire Detection and Suppression (FDS), Temperature and Humidity Control (THC), and Water Recovery and Management (WRM). This paper provides a summary of the nominal operation of the Node 1 ACS, AR, and WRM design and detailed Element Verification methodologies utilized during the Qualification phase for Node 1.
\end{abstract}

\section{INTRODUCTION}

Node 1 flew to ISS on Flight 2A. It was the first module of the United States On-Orbit Segment (USOS) that was launched to ISS. The Node 1 ISS ECLS design featured limited ECLS capability. The main purpose of Node 1 was to provide internal storage by providing four stowage rack locations within the module and to allow docking of multiple modules and a truss segment to it.

Of the five Node 1 ECLS subsystems this paper will only address the nominal operation of the ACS, AR, and WRM subsystems. The nominal operation of the Node 1 ACS, AR, and WRM subsystems capabilities can be subdivided into their sub-allocated functions. The Node 1 ACS consists of: 1) a cabin pressure sensor for monitoring total pressure in the Node 1 cabin, 2) lines for routing low-pressure oxygen and nitrogen, 3) Joint Airlock Depressurization Pump Assembly (DPA) outlet line, 4) lines for routing high-pressure oxygen and nitrogen, and 6) manual pressure equalization valves to reduce the pressure differential across the hatch prior to opening the hatch. The Node 1 AR consists of sample lines for routing air samples to the Major Constituent Analyzer (MCA) in the U.S. Laboratory Module or in Node 3. The Node 1 WRM consists of: 1) lines for routing excess Space Shuttle Fuel Cell water or Regen- erative ECLS Water Processor Assembly (WPA) potable water and 2) lines for routing waste water, i.e. condensate from the USOS condensing heat exchangers and waste water from the Extravehicular Activity (EVA) space suits.

The Verification of the ISS hardware is accomplished using a building block process. Verification starts at the Component Level and progresses until the Element Level Verification is complete. The primary objective of the Qualification Verification program is to ensure that the subsystems meet the section three requirements in the Prime Item Development Specifications (PIDS). The PIDS dictates whether a section three requirement is verified by test, analysis, inspection, and/or demonstration, as documented in section four of the PIDS.

Node 1 is a Protoflight Test Article since no Element Qualification Test Article exists. Therefore, no additional ground testing or evaluations can be performed on Node 1 after it has been installed into the space Shuttle Payload Bay and launched to ISS. Node 1 is shown in Figure 1 during processing at Kennedy Space Center (KSC) and in flight during the Flight $2 \mathrm{~A}$ series of Flights (i.e., Flights 2A, 2A.1, 2A.2a, and 2A.2b).

\section{SUBSYSTEM OVERVIEWS}

A general overview of the nominal operation of the Node 1 ACS, AR, and WRM subsystem is provided below.

$\underline{\text { ACS: }}$

The Node 1 ACS hardware, as shown in Figure 2, consists of a single cabin pressure sensor that can monitor the Node 1 cabin pressure between 0 to 104.8 $\mathrm{kPa}$ (0 to $15.2 \mathrm{psia}$ ), low-pressure oxygen and nitrogen distribution lines, low-pressure oxygen and nitrogen manual isolation provided by quick disconnects (QDs), a 


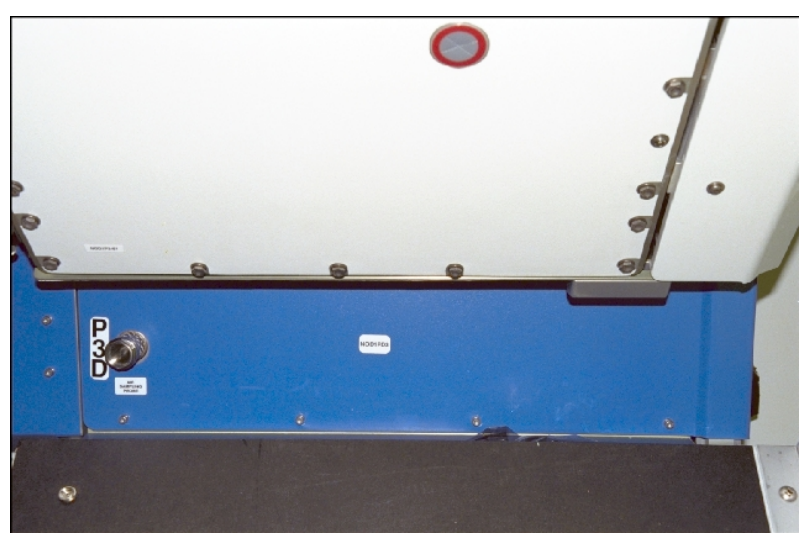

Node 1 Sample Probe

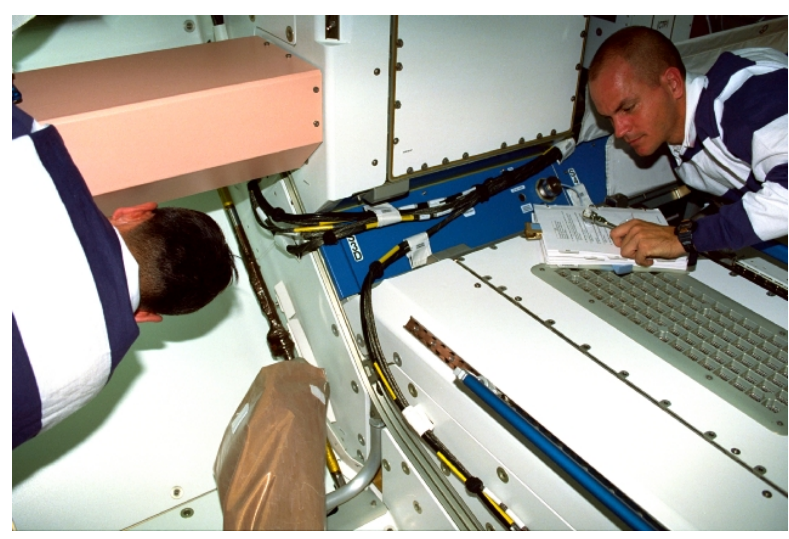

Node 1 Cabin Pressure Sensor

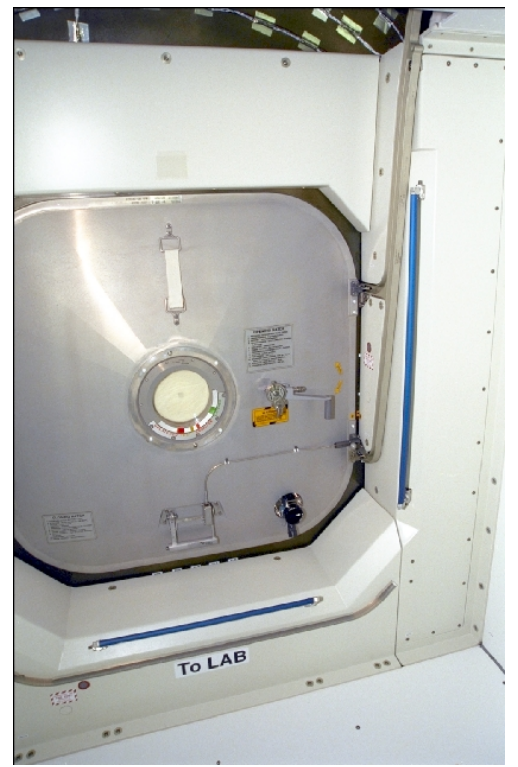

Node 1 Manual Pressure Equalization Valve

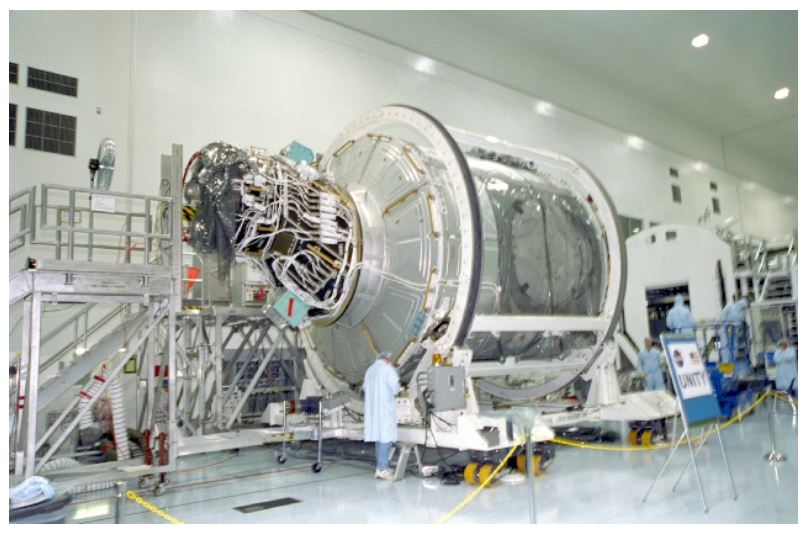

PMA 1 and Node 1 at KSC

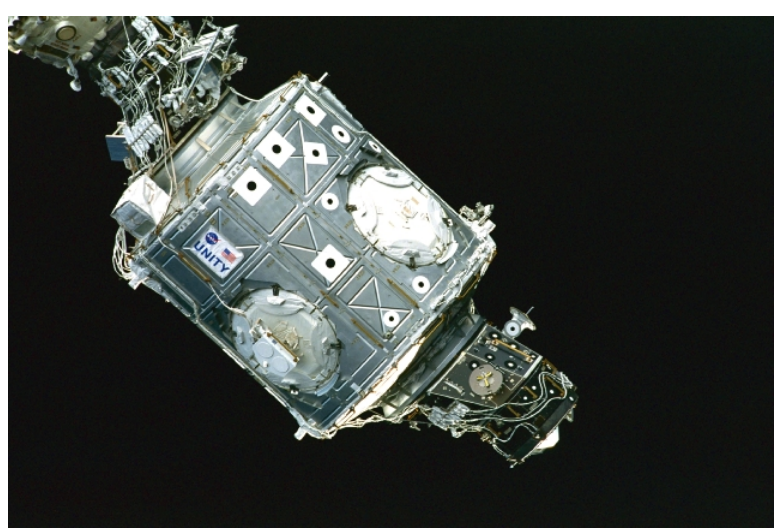

Node 1, PMA 1, and PMA 2 during Flight 2A

Figure 1 - Node 1 during processing at KSC and In Flight during the Flight 2A Series of Flights 


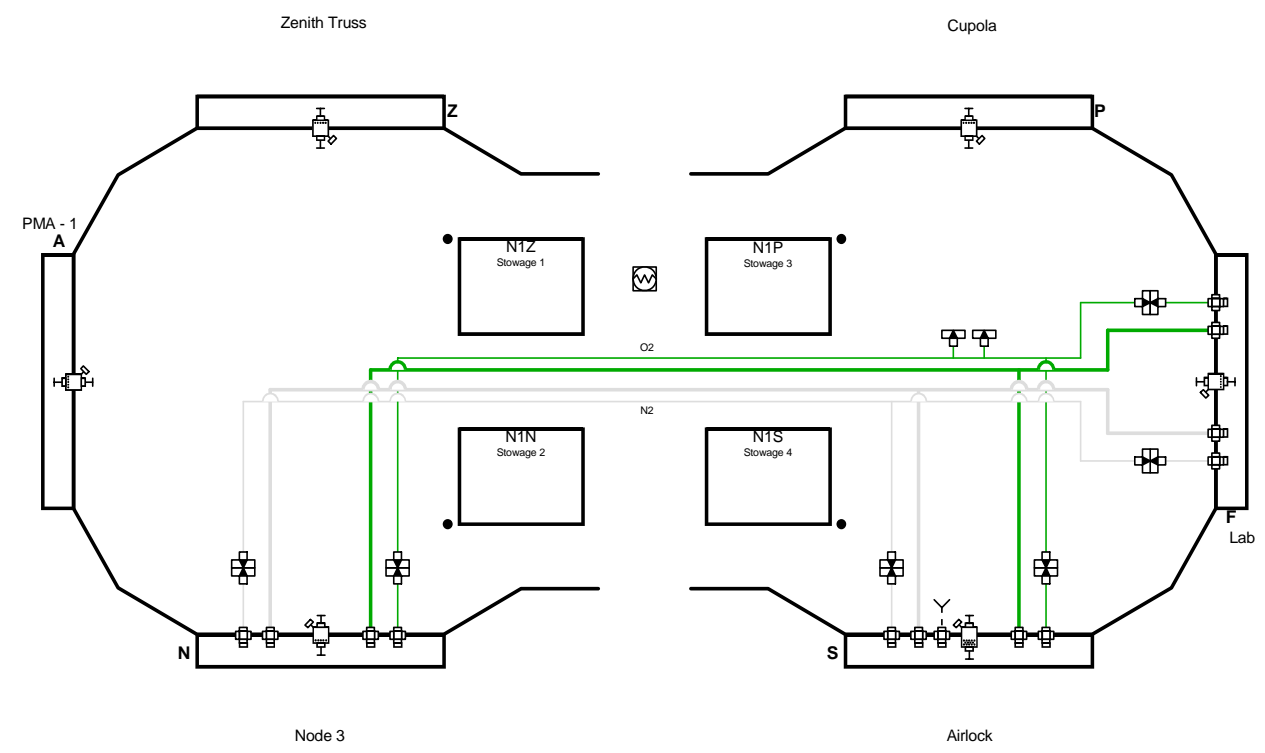

Figure 2 - Node 1 Atmosphere Control and Supply Schematic

Joint Airlock DPA outlet line, high-pressure oxygen and nitrogen distribution lines, and a single manual pressure equalization valve (MPEV) in each of the six Node 1 hatches.

The low-pressure oxygen line runs from the Node 1 starboard hatch interface (the Joint Airlock interface) to the Node 1 forward interface (the United States [U.S.] Laboratory Module interface) and to the Node 1 nadir hatch interface (the Node 3 interface). The lines are made up of a combination of hard lines and flexible hoses. The line supplies oxygen to users in Node 3, in the U.S. Laboratory Module, and to elements downstream of the U.S. Laboratory Module. In case of a leak in the low-pressure oxygen line the distribution can be isolated at the Node 1 starboard, nadir, and forward interfaces by disconnecting the male and female half of the QD at the required interfaces.

The low-pressure nitrogen line runs from the Node 1 starboard hatch interface to the Node 1 forward interface and to the Node 1 nadir hatch interface. The lines are made up of hard lines and flexible hoses. The line supplies nitrogen to users in Node 3 , in the U.S. Laboratory Module, and to elements downstream of the U.S. Laboratory Module. In case of a leak in the low pressure nitrogen line the distribution can be isolated at the Node 1 starboard, nadir, and forward interfaces by disconnecting the male and female half of the QD at the required interfaces.

The Joint Airlock DPA outlet line provides an outlet for the Joint Airlock air to the Node 1 cabin at the Node 1 starboard interface when the air being pumped out of the Joint Airlock by the DPA to support $70.3 \mathrm{kPa}$ (10.2 psia) operation in the Joint Airlock or when the Joint Airlock Crewlock is being pumped down as part of the preparation for the EVA crew members to exit the Joint Airlock Crewlock to space vacuum. It consists of a flexible hose that runs from the Node 1 starboard bulkhead to the Node $1 \mathrm{IMV}$ return ducting. This flexible hose was installed on-orbit by the ISS crew after the delivery of the Joint Airlock.

The high-pressure oxygen and nitrogen lines run from the Node 1 nadir hatch interface and the Node 1 forward interface to the Node 1 starboard hatch interface. The lines are made up of hard lines and flexible hoses. The high-pressure oxygen and nitrogen lines are part of the distribution for transferring excess Space Shuttle oxygen and nitrogen gas from the Space Shuttle to the Joint Airlock for storage in the Joint Airlock oxygen and nitrogen tanks. There is no isolation capability for the high-pressure oxygen and nitrogen lines in Node 1. The isolation capability for this subsystem is located in the Space Shuttle oxygen and nitrogen distribution subsystem, in Pressurized Mating Adapter (PMA) 2/3, and in the Joint Airlock.

The MPEVs are located in each of the Node 1 hatches. They are designed for bi-directional flow and they are designed to be manually operated from both sides of the hatch with no electrical or data system interfaces. On the Node 1 side of the hatch the MPEVs have a vacuum access jumper hose interface to allow depressurization of the vestibule, which is the small area between the attached modules, depressurization of the attached element, and to allow monitoring the atmosphere on the other side of the hatch without opening it.

\section{AR:}

The MCA sample distribution lines in Node 1 , as shown in Figure 3, consists of four electrical 3-way valves, three manual isolation valves, a sample probe, hard lines, and flexible hoses. It allows the MCA in the 


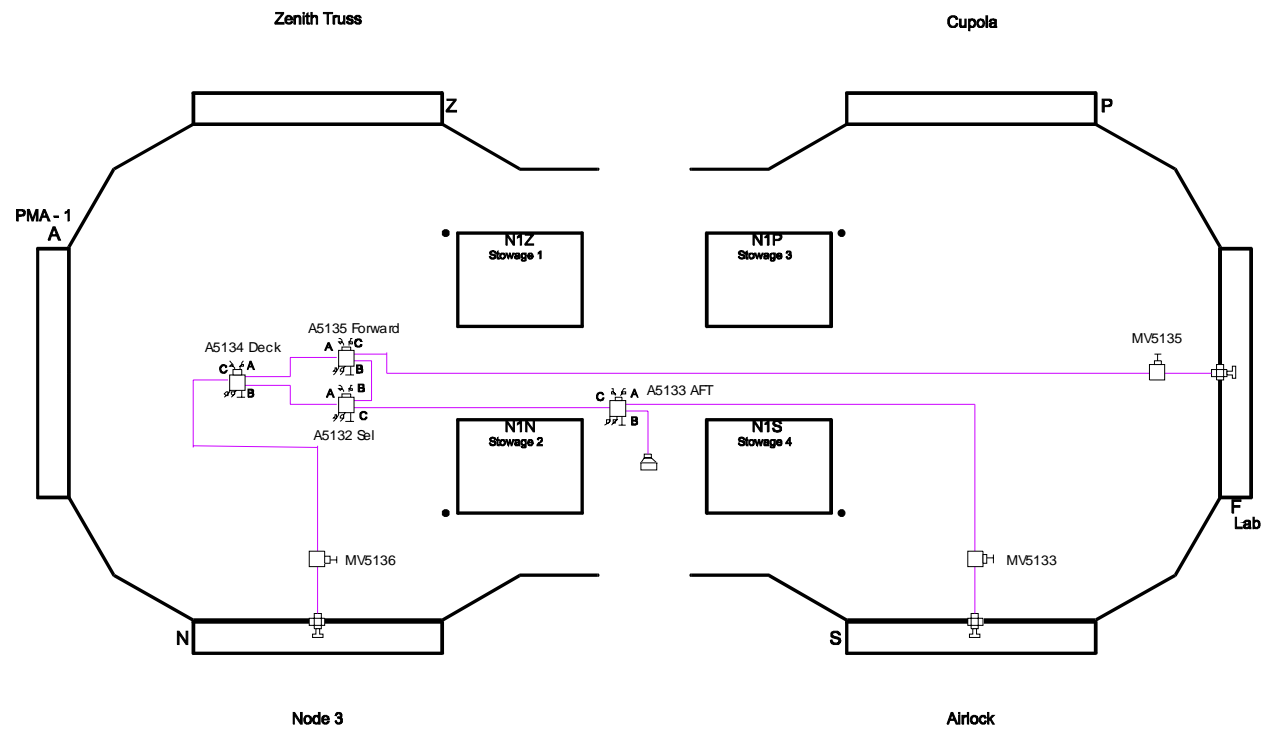

Figure 3 - Node 1 Atmosphere Revitalization Schematic

U.S. Laboratory module or in Node 3 to sample and monitor the major constituents (partial pressure of nitrogen [ppN2], partial pressure of oxygen [ppO2], partial pressure of carbon dioxide [ppCO2], partial pressure of water vapor $[\mathrm{ppH} 2 \mathrm{O}]$, partial pressure of hydrogen $[\mathrm{ppH} 2]$, and the partial pressure of methane [ppCH4]) in Node 1, to transfer a cabin air sample from the Joint Airlock to the U.S. Laboratory module MCA, to transfer a cabin air sample from the Joint Airlock to the Node $3 \mathrm{MCA}$, to transfer a Node 3 or Mini-Pressurized Logistic Module (MPLM) [the name for the MPLM was changed from Mini-Pressurized Logistic Module to MultiPurpose Logistic Module later in the Program] cabin air samples to the U.S. Laboratory module MCA, and to transfer a cabin air sample from the U.S. Laboratory module and from modules forward of the U.S. Laboratory to the Node $3 \mathrm{MCA}$.

\section{WRM:}

The Node 1 WRM consists of the Fuel Cell Water distribution and the Waste Water distribution.

The Fuel Cell Water line runs from the Node 1 forward interface to the Node 1 nadir hatch interface, as shown in Figure 4. The lines are made up of hard lines, flexible hoses, and QDs. The Fuel Cell Water line transfers excess Space Shuttle Fuel Cell water to the scarred location in the U.S. Laboratory Module for the Fuel Cell Water Storage Rack, to transfer stored excess Space Shuttle Fuel Cell water from the scarred Fuel Cell Water Storage Rack to Node 3 users, or to transfer potable water from the Regenerative ECLS WPA in Node 3 to users in the U.S. Laboratory Module. In case of a leak in the Fuel Cell Water line the distribution can be isolated at the Node 1 forward and nadir interfaces by disconnecting the male and female half of the QD at the required interfaces.
The Waste Water line runs from the Node 1 starboard interface to the Node 1 forward interface or to the Node 1 nadir interface, and it supports the transport of waste water between the Node 1 forward interface to the Node 1 nadir interface, as shown in Figure 4 . The lines are made up of hard lines, flexible hoses, and QDs. The Waste Water lines transfer condensate and EVA suit waste water to the U.S. Laboratory Module condensate storage tank or to the Node 3 Regenerative ECLS WPA. In case of a leak in the Waste Water line the distribution can be isolated at the Node 1 starboard, forward and nadir interfaces by disconnecting the male and female half of the QD at the required interfaces.

\section{ELEMENT LEVEL VERIFICATION PROGRAM}

\section{Node 1 ACS QUALIFICATION METHODOLOGY:}

\section{Cabin Pressure Monitoring:}

\begin{tabular}{|c|c|}
\hline Requirement & Verification \\
\hline $\begin{array}{l}\text { Node } 1 \text { shall monitor } \\
\text { cabin atmosphere } \\
\text { pressure in the range of } 0 \\
\text { to } 15.2 \text { psia, and provide } \\
\text { a proportional current } \\
\text { representing the pressure, } \\
\text { accurate to within }+/-0.35 \\
\text { psia, at the PMA-1 } \\
\text { interface as specified in } \\
\text { SSP } 42122 \text {, paragraph } \\
\text { 3.2.1.5.4.1. }\end{array}$ & $\begin{array}{l}\text { The Node } 1 \text { monitor total pressure } \\
\text { requirement shall be verified by analysis. } \\
\text { Analysis of the Node } 1 \text { end-to-end } \\
\text { pressure monitoring and reporting } \\
\text { scheme shall be performed to determine } \\
\text { measurement and reporting accuracy. } \\
\text { Analysis determination of the accuracy of } \\
\text { the current at the Node } 1 / \text { PMA-1 } \\
\text { interface as representative of the } \\
\text { pressure in the range from } 0 \text { to } 15.2 \text { psia. } \\
\text { Verification shall be considered } \\
\text { successful when analysis shows the } \\
\text { current at the Node 1/PMA-1 interface } \\
\text { provides direct correlation to the internal } \\
\text { pressure as specified in SSP } 42122 \text {, } \\
\text { paragraph } 3.2 .1 .5 .4 .1 \text {, within }+/-0.35 \text { psia } \\
\text { of the actual pressure throughout }\end{array}$ \\
\hline
\end{tabular}




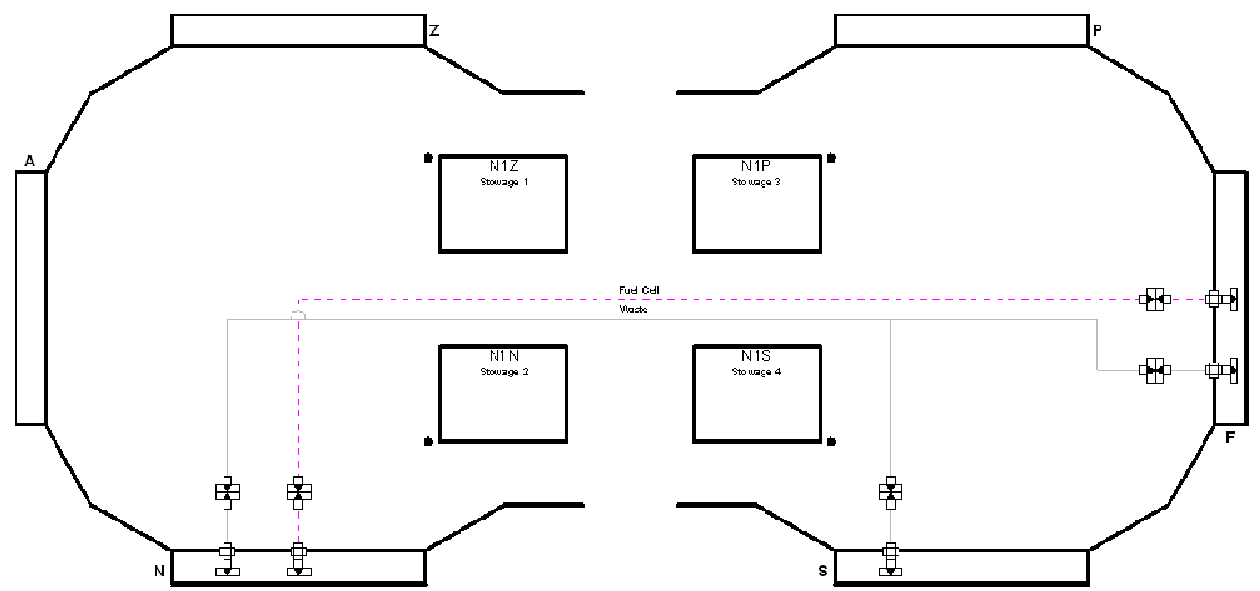

Figure 4 - Node 1 Water Recovery and Management Schematic

\begin{tabular}{|c|l|}
\hline $\begin{array}{c}\text { Requirement } \\
\text { (cont'd) }\end{array}$ & \multicolumn{1}{c|}{$\begin{array}{c}\text { Verification } \\
\text { (cont'd) }\end{array}$} \\
\hline & $\begin{array}{l}\text { the entire range of 0 to 15.2 psia. Node 1 } \\
\text { end item testing shall monitor ambient } \\
\text { pressure. }\end{array}$ \\
\hline
\end{tabular}

\begin{tabular}{|c|c|}
\hline $\begin{array}{c}\text { SSP } 42122 \\
\text { Interface Parameters }\end{array}$ & $\begin{array}{l}\text { From/To PMA-1 } \\
\text { and Node } 1\end{array}$ \\
\hline Node 1 ECLS Signals & $\begin{array}{l}\text { The Node } 1 \text { shall provide to and receive } \\
\text { from PMA-1 instrumentation signals for } \\
\text { the monitoring and control of the } \\
\text { following ECLSS equipment by the N1-1 } \\
\text { MDM: Atmosphere Revitalization valves, } \\
\text { Smoke Detector, Node } 1 \text { Air Mixing } \\
\text { Valve, Cabin Fan, Node } 1 \text { Aft IMV Fan, } \\
\text { Node } 1 \text { Aft IMV Return and Supply } \\
\text { Valves, Node } 1 \text { Starboard Return and } \\
\text { Supply valves, Node } 1 \text { Port Supply valve, } \\
\text { Node } 1 \text { Rheostat. The interface between } \\
\text { the Node } 1 \text { ECLSS equipment and the } \\
\text { N1-1 MDM shall be in compliance with } \\
\text { SSP } 30261: 002 \text {. } \\
\text { The Node } 1 \text { shall provide and receive } \\
\text { from PMA-1 instrumentation signals for } \\
\text { the monitoring and control of the } \\
\text { following ECLSS equipment by the N1-2 } \\
\text { MDM: Cabin Pressure sensor, Smoke } \\
\text { Detector, Cupola Air Mixing Valve, Node } \\
1 \text { Port and Starboard IMV Fans, Node } 1 \\
\text { Nadir IMV Return and Supply valves, } \\
\text { Node } 1 \text { Forward Return and Supply } \\
\text { valves, Cupola Rheostat. The interface } \\
\text { between the Node } 1 \text { ECLSS equipment } \\
\text { and the N1-2 MDM shall be in } \\
\text { compliance with SSP } 30261: 002 \text {. }\end{array}$ \\
\hline
\end{tabular}

Boeing - Huntington Beach analyzed the error for the cabin pressure sensor, the error from the wire run between the cabin pressure sensor and the Multiplexer/ Demultiplexer (MDM), and the error from the MDM.
Boeing - Huntington Beach also noted that the cabin pressure sensor data from the equipment supplier supported the required range of $0-104.8 \mathrm{kPa}(0-15.2$ psia).

\section{$\underline{\text { Results: }}$}

The calculated sensor error for monitoring cabin pressure in Node 1 was $+/-2.28 \mathrm{kPa}(0.33 \mathrm{psia})$ vs. the required level of $+/-2.41 \mathrm{kPa}(0.35 \mathrm{psia})$. The analysis results are very conservative since Boeing - Huntington Beach used the specified cabin pressure sensor error, the maximum transmission wire loss at the maximum current, and the specified MDM induced error. The cabin pressure sensor went through a Qualification Program to show that the cabin pressure sensor specified error of $1.65 \mathrm{kPa}(0.24$ psia) was very conservative.

Based on the analysis results, the Node 1 cabin pressure sensor met the range and accuracy requirements.

\section{Low-Pressure and High-Pressure Oxygen Distribution:}

\begin{tabular}{|l|l|}
\hline \multicolumn{1}{|c|}{ Requirement } & \multicolumn{1}{c|}{ Verification } \\
\hline $\begin{array}{l}\text { Node 1 shall receive } \\
\text { recharge oxygen at either } \\
\text { the USL or Node 3 } \\
\text { interface and provide it to } \\
\text { the Airlock interface as } \\
\text { specified in SSP 41145, } \\
\text { paragraph 3.2.1.3.9. }\end{array}$ & $\begin{array}{l}\text { The Node 1 capability to distribute } \\
\text { oxygen to the adjacent elements shall be } \\
\text { verified by analysis. An analysis shall be } \\
\text { conducted to evaluate oxygen pressure } \\
\text { loss characteristics for all the distributed } \\
\text { lines based upon pressure, temperature, } \\
\text { and flow interface characteristics } \\
\text { recharge oxygen received } \\
\text { from the USL and Node 3 } \\
\text { interfaces are as specified } \\
\text { in SSP 41141, paragraph } \\
\begin{array}{l}\text { S.2.1.2.13 and SSP } \\
\text { referenced requirements in SSP 411414, and SSP 41145. } \\
\text { S.2.1.2.12, respectively. }\end{array} \\
\begin{array}{l}\text { Analysis shall similarly be conducted for } \\
\text { recharge oxygen distribution lines during }\end{array} \\
\text { gas transfer to ISS based upon pressure, } \\
\text { temperature, }\end{array}$ \\
\hline
\end{tabular}


Requirement (cont'd)

Node 1 shall receive oxygen at the Airlock interface and provide it to the USL and Node 3 interfaces as specified in SSP 41141, paragraph 3.2.1.2.3 and SSP 41140 paragraph 3.2.1.2.3,

respectively.

Characteristics of oxygen received at the Airlock interface are as specified in SSP 41145, paragraph 3.2.1.3.3. Oxygen flow is required to both the USL and the Node 3 , but not both simultaneously.

Node 1 shall provide for selective manual isolation of oxygen flow at the

Airlock, USL, and Node 3 interfaces. This

requirement does not apply to recharge oxygen flow.

The requirement references three ISS Interface Control Documents (ICDs). The relevant requirements from those documents are as follows for low-pressure and high-pressure oxygen:

Low-Pressure Oxygen:

\begin{tabular}{|l|c|l|}
\hline $\begin{array}{c}\text { SSP 41140 } \\
\text { Interface } \\
\text { Parameters }\end{array}$ & $\begin{array}{c}\text { From Node } 3 \text { to } \\
\text { Node } 1\end{array}$ & $\begin{array}{c}\text { To Node } 3 \text { from } \\
\text { Node } 1\end{array}$ \\
\hline Temperature & N/A & $\begin{array}{l}54 \text { to } 113^{\circ} \mathrm{F}(12.2 \text { to } \\
\left.45^{\circ} \mathrm{C}\right)\end{array}$ \\
\hline Flow Rate & N/A & $\begin{array}{l}0-0.2 \mathrm{lbm} / \mathrm{min}(0- \\
0.09 \mathrm{~kg} / \mathrm{min})\end{array}$ \\
\hline $\begin{array}{l}\text { Nominal Pressure } \\
\text { Range }\end{array}$ & N/A & $\begin{array}{l}93-120 \mathrm{psia}(641.2- \\
827.4 \mathrm{kPa})\end{array}$ \\
\hline Maximum Pressure & N/A & $200 \mathrm{psia}(1379 \mathrm{kPa})$ \\
\hline
\end{tabular}

\begin{tabular}{|l|c|l|}
\hline $\begin{array}{c}\text { SSP 41141 } \\
\text { Interface } \\
\text { Parameters }\end{array}$ & $\begin{array}{c}\text { From U.S. } \\
\text { Laboratory } \\
\text { Module to } \\
\text { Node } 1\end{array}$ & $\begin{array}{c}\text { To U.S. } \\
\text { Laboratory } \\
\text { Module from } \\
\text { Node } 1\end{array}$ \\
\hline Temperature & N/A & $\begin{array}{l}54 \text { to } 113^{\circ} \mathrm{F}(12.2 \text { to } \\
\left.45^{\circ} \mathrm{C}\right)\end{array}$ \\
\hline Flow Rate & N/A & $\begin{array}{l}0-0.2 \mathrm{lbm} / \mathrm{min}(0- \\
0.09 \mathrm{~kg} / \mathrm{min})\end{array}$ \\
\hline $\begin{array}{l}\text { Nominal Pressure } \\
\text { Range }\end{array}$ & N/A & $\begin{array}{l}93-120 \mathrm{psia}(641.2- \\
827.4 \mathrm{kPa})\end{array}$ \\
\hline Maximum Pressure & N/A & $200 \mathrm{psia}(1379 \mathrm{kPa})$ \\
\hline
\end{tabular}

\begin{tabular}{|l|l|c|}
\hline $\begin{array}{c}\text { SSP 41145 } \\
\text { Interface } \\
\text { Parameters }\end{array}$ & \multicolumn{1}{|c|}{$\begin{array}{c}\text { From Joint } \\
\text { Airlock to } \\
\text { Node 1 }\end{array}$} & $\begin{array}{c}\text { To Joint Airlock } \\
\text { from Node 1 }\end{array}$ \\
\hline Temperature & $\begin{array}{l}47 \text { to } 113^{\circ} \mathrm{F}(8.3 \text { to } \\
\left.45^{\circ} \mathrm{C}\right)\end{array}$ & N/A \\
\hline Flow Rate & $\begin{array}{l}\leq 0.2 \mathrm{lbm} / \mathrm{min}(0.09 \\
\mathrm{kg} / \mathrm{min})\end{array}$ & N/A \\
\hline $\begin{array}{l}\text { Nominal Pressure } \\
\text { Range }\end{array}$ & $\begin{array}{l}95-120 \mathrm{psia}(655.0- \\
827.4 \mathrm{kPa})\end{array}$ & N/A \\
\hline
\end{tabular}

Boeing - Huntington Beach analyzed the pressure loss of the Node 1 low-pressure oxygen distribution from the Node 1 starboard interface to the Node 1 forward and also to the Node 1 nadir interface at the maximum specified flow rate, temperature, and the initial nominal pressure, but not to both interfaces simultaneously.

Results:

The calculated pressure loss for the low-pressure oxygen distribution was $6.38 \mathrm{kPa}$ differential (0.926 psid) from the Node 1 starboard interface to the Node 1 nadir interface and was $5.64 \mathrm{kPa}$ differential (0.818 psid) from the Node 1 starboard interface to the Node 1 forward interface. The analysis result for this subsystem is considered to be conservative since Boeing Huntington Beach used the flex hose pressure drop that was recommended by Boeing - Huntsville, which was shown to be conservative when compared to the results from a flex hose development test. Boeing - Huntington Beach also used the QD specified pressure drop data in the analysis. This data was shown to be conservative since the specified pressure drop for the QD was higher than the actual Qualification Program data.

Based on the analysis results, Node 1 met the pressure loss requirement for the low-pressure oxygen distribution.

High-Pressure Oxygen:

\begin{tabular}{|l|l|c|}
\hline $\begin{array}{c}\text { SSP 41140 } \\
\text { Interface } \\
\text { Parameters }\end{array}$ & \multicolumn{1}{|c|}{$\begin{array}{c}\text { From Node } 3 \text { to } \\
\text { Node } 1\end{array}$} & $\begin{array}{c}\text { To Node 3 from } \\
\text { Node } 1\end{array}$ \\
\hline Temperature & $\begin{array}{l}25 \text { to } 113^{\circ} \mathrm{F}(-3.9 \text { to } \\
\left.45^{\circ} \mathrm{C}\right)\end{array}$ & N/A \\
\hline Flow Rate & $\begin{array}{l}\leq 16 \mathrm{lbm} / \mathrm{hr}(7.3 \\
\mathrm{kg} / \mathrm{hr})\end{array}$ & N/A \\
\hline $\begin{array}{l}\text { Nominal Pressure } \\
\text { Range }\end{array}$ & $\begin{array}{l}750-1050 \mathrm{psia}(5.2- \\
7.2 \mathrm{MPa})\end{array}$ & N/A \\
\hline
\end{tabular}

\begin{tabular}{|l|l|c|}
\hline $\begin{array}{c}\text { SSP 41141 } \\
\text { Interface } \\
\text { Parameters }\end{array}$ & $\begin{array}{c}\text { From U.S. } \\
\text { Laboratory } \\
\text { Module to } \\
\text { Node } 1\end{array}$ & $\begin{array}{c}\text { To U.S. } \\
\text { Laboratory } \\
\text { Module from } \\
\text { Node } 1\end{array}$ \\
\hline Temperature & $\begin{array}{l}25 \text { to } 113^{\circ} \mathrm{F}(-3.9 \text { to } \\
\left.45^{\circ} \mathrm{C}\right)\end{array}$ & $\mathrm{N} / \mathrm{A}$ \\
\hline Flow Rate & $\begin{array}{l}\leq 16 \mathrm{lbm} / \mathrm{hr}(7.3 \\
\mathrm{kg} / \mathrm{hr})\end{array}$ & $\mathrm{N} / \mathrm{A}$ \\
\hline $\begin{array}{l}\text { Nominal Pressure } \\
\text { Range }\end{array}$ & $\begin{array}{l}750-1050 \mathrm{psia}(5.2- \\
7.2 \mathrm{MPa})\end{array}$ & $\mathrm{N} / \mathrm{A}$ \\
\hline
\end{tabular}

\begin{tabular}{|l|c|l|}
\hline $\begin{array}{c}\text { SSP 41145 } \\
\text { Interface } \\
\text { Parameters }\end{array}$ & $\begin{array}{c}\text { From Joint } \\
\text { Airlock to } \\
\text { Node } 1\end{array}$ & $\begin{array}{l}\text { To Joint Airlock } \\
\text { from Node } 1\end{array}$ \\
\hline Temperature & N/A & $\begin{array}{l}25 \text { to } 113^{\circ} \mathrm{F}(-3.9 \text { to } \\
\left.45^{\circ} \mathrm{C}\right)\end{array}$ \\
\hline Flow Rate & $\mathrm{N} / \mathrm{A}$ & $\begin{array}{l}\leq 16 \mathrm{lbm} / \mathrm{hr}(7.3 \\
\mathrm{kg} / \mathrm{hr})\end{array}$ \\
\hline $\begin{array}{l}\text { Nominal Pressure } \\
\text { Range }\end{array}$ & $\mathrm{N} / \mathrm{A}$ & $\begin{array}{l}750-1050 \mathrm{psia}(5.2- \\
7.2 \mathrm{MPa})\end{array}$ \\
\hline
\end{tabular}


Boeing - Huntington Beach analyzed the pressure loss of the Node 1 high-pressure oxygen distribution from the Node 1 forward or Node 1 nadir interface to the

Node 1 starboard interface at the maximum specified flow rate, temperature, and nominal pressure.

\section{$\underline{\text { Results: }}$}

The calculated pressure loss for the high-pressure oxygen distribution was $0.55 \mathrm{kPa}$ differential (0.080 psid) from the Node 1 nadir interface to the Node 1 starboard interface and was $0.53 \mathrm{kPa}$ differential $(0.077 \mathrm{psid})$ from the Node 1 forward interface to the Node 1 starboard interface. The analysis result for this subsystem is considered to be conservative since Boeing Huntington Beach used the flex hose pressure drop that was recommended by Boeing - Huntsville, which was shown to be conservative when compared to the results from a flex hose development test.

The requirement for this subsystem did not have any pressure loss pass/fail requirement but the value was very low and it was agreed based on that fact that the analysis part of the verification was acceptable.

\section{Low-Pressure and High-Pressure Nitrogen Distribution:}

\begin{tabular}{|c|c|}
\hline Requirement & Verification \\
\hline $\begin{array}{l}\text { Node } 1 \text { shall provide } \\
\text { recharge nitrogen, } \\
\text { received at either the USL } \\
\text { or Node } 3 \text { interface, to the } \\
\text { Airlock interface as } \\
\text { specified in SSP } 41145, \\
\text { paragraph } 3.2 .1 .3 .10 \text {. } \\
\text { Characteristics of } \\
\text { recharge nitrogen } \\
\text { received from the USL } \\
\text { and Node } 3 \text { interfaces are } \\
\text { as specified in SSP } \\
41141, \text { paragraph } \\
3.2 .1 .2 .14 \text { and SSP } \\
41140, \text { paragraph } \\
3.2 .1 .2 .13, \text { respectively. } \\
\text { Node } 1 \text { shall provide } \\
\text { nitrogen, received at the } \\
\text { Airlock interface, to the } \\
\text { USL and Node } 3 \\
\text { interfaces, as specified in } \\
\text { SSP } 41141, \text { paragraph } \\
\text { 3.2.1.2.4 and SSP } 41140 \text {, } \\
\text { paragraph } 3.2 .1 .2 .4 \text {, } \\
\text { respectively. } \\
\text { Characteristics of nitrogen } \\
\text { received at the Airlock } \\
\text { interface are as specified } \\
\text { in SSP } 41145, \text { paragraph } \\
3.2 .1 .3 .4 \text {. Required } \\
\text { nitrogen flow is to both the } \\
\text { USL and Node } 3 \\
\text { interfaces, but not both } \\
\text { simultaneously. } \\
\text { Node } 1 \text { shall provide for } \\
\text { selective manual shut off } \\
\text { of nitrogen flow at the } \\
\text { Airlock, USL, and Node } 3 \\
\text { interfaces. This }\end{array}$ & $\begin{array}{l}\text { The Node } 1 \text { capability to distribute } \\
\text { nitrogen to the adjacent elements shall } \\
\text { be verified by analysis. An analysis shall } \\
\text { be conducted to evaluate nitrogen } \\
\text { pressure loss characteristics for all the } \\
\text { distributed lines based upon pressure, } \\
\text { temperature, and flow interface } \\
\text { characteristics specified in the } \\
\text { appropriate ICDs referenced } \\
\text { requirements in SSP } 41140, \text { SSP } 41141 \text {, } \\
\text { and SSP } 41145 \text {. } \\
\text { Analysis shall similarly be conducted for } \\
\text { recharge nitrogen distribution lines during } \\
\text { gas transfer to ISS based upon pressure, } \\
\text { temperature, and flow interface } \\
\text { characteristics specified in the } \\
\text { appropriate ICDs. } \\
\text { The verification shall be considered } \\
\text { successful when the analysis proves that } \\
\text { interface conditions at each adjacent } \\
\text { element port are met as specified in } \\
\text { referenced ICDs. }\end{array}$ \\
\hline
\end{tabular}

requirement does not

apply to recharge nitrogen

flow.

The requirement references three ISS ICDs. The relevant requirements from those documents are as follows for low-pressure and high-pressure nitrogen:

Low-Pressure Nitrogen:

\begin{tabular}{|l|c|l|}
\hline $\begin{array}{c}\text { SSP 41140 } \\
\text { Interface } \\
\text { Parameters }\end{array}$ & $\begin{array}{c}\text { From Node } 3 \text { to } \\
\text { Node } 1\end{array}$ & \multicolumn{1}{|c|}{$\begin{array}{c}\text { To Node } 3 \text { from } \\
\text { Node } 1\end{array}$} \\
\hline Temperature & N/A & $\begin{array}{l}60 \text { to } 113^{\circ} \mathrm{F}(15.6 \text { to } \\
\left.45^{\circ} \mathrm{C}\right)\end{array}$ \\
\hline Flow Rate & N/A & $\begin{array}{l}0-0.2 \mathrm{lbm} / \mathrm{min}(0- \\
0.09 \mathrm{~kg} / \mathrm{min})\end{array}$ \\
\hline $\begin{array}{l}\text { Nominal Pressure } \\
\text { Range }\end{array}$ & N/A & $\begin{array}{l}93-120 \mathrm{psia}(641.2- \\
827.4 \mathrm{kPa})\end{array}$ \\
\hline Maximum Pressure & N/A & $200 \mathrm{psia}(1379 \mathrm{kPa})$ \\
\hline
\end{tabular}

\begin{tabular}{|l|c|l|}
\hline $\begin{array}{c}\text { SSP 41141 } \\
\text { Interface } \\
\text { Parameters }\end{array}$ & $\begin{array}{c}\text { From U.S. } \\
\text { Laboratory } \\
\text { Module to } \\
\text { Node } 1\end{array}$ & $\begin{array}{c}\text { To U.S. } \\
\text { Laboratory } \\
\text { Module from } \\
\text { Node } 1\end{array}$ \\
\hline Temperature & N/A & $\begin{array}{l}60 \text { to } 113^{\circ} \mathrm{F}(15.6 \text { to } \\
\left.45^{\circ} \mathrm{C}\right)\end{array}$ \\
\hline Flow Rate & N/A & $\begin{array}{l}0-0.2 \mathrm{lbm} / \mathrm{min}(0- \\
0.09 \mathrm{~kg} / \mathrm{min})\end{array}$ \\
\hline Nominal Pressure & N/A & $\begin{array}{l}93-120 \mathrm{psia}(641.2- \\
827.4 \mathrm{kPa})\end{array}$ \\
Range & N/A & $200 \mathrm{psia}(1379 \mathrm{kPa})$ \\
\hline Maximum Pressure & & \\
\hline
\end{tabular}

\begin{tabular}{|l|l|c|}
\hline \multicolumn{1}{|c|}{$\begin{array}{c}\text { SSP 41145 } \\
\text { Interface } \\
\text { Parameters }\end{array}$} & \multicolumn{1}{|c|}{$\begin{array}{c}\text { From Joint } \\
\text { Airlock to } \\
\text { Node } 1\end{array}$} & $\begin{array}{c}\text { To Joint Airlock } \\
\text { from Node } 1\end{array}$ \\
\hline Temperature & $\begin{array}{l}54 \text { to } 113^{\circ} \mathrm{F}(12.2 \text { to } \\
\left.45^{\circ} \mathrm{C}\right)\end{array}$ & $\mathrm{N} / \mathrm{A}$ \\
\hline Flow Rate & $\begin{array}{l}0-0.2 \mathrm{lbm} / \mathrm{min}(0- \\
0.09 \mathrm{~kg} / \mathrm{min})\end{array}$ & $\mathrm{N} / \mathrm{A}$ \\
\hline $\begin{array}{l}\text { Nominal Pressure } \\
\text { Range }\end{array}$ & $\begin{array}{l}95-120 \mathrm{psia}(655.0- \\
827.4 \mathrm{kPa})\end{array}$ & $\mathrm{N} / \mathrm{A}$ \\
\hline Maximum Pressure & $200 \mathrm{psia}(1379 \mathrm{kPa})$ & $\mathrm{N} / \mathrm{A}$ \\
\hline
\end{tabular}

Boeing - Huntington Beach analyzed the pressure loss of the Node 1 low-pressure nitrogen distribution from the Node 1 starboard interface to the Node 1 forward and also to the Node 1 nadir interface at the maximum specified flow rate, temperature, and the initial nominal pressure, but not to both interfaces simultaneously.

\section{Results:}

The calculated pressure loss for the low-pressure nitrogen distribution was $6.89 \mathrm{kPa}$ differential (0.999 psid) from the Node 1 starboard interface to the Node 1 nadir interface and was $6.13 \mathrm{kPa}$ differential (0.889 psid) from the Node 1 starboard interface to the Node 1 forward interface. The analysis result for this subsystem is considered to be conservative since Boeing Huntington Beach used the flex hose pressure drop that was recommended by Boeing - Huntsville, which was shown to be conservative when compared to the results 
from a flex hose development test. Boeing - Huntington Beach also used the QD specified pressure drop data in the analysis. This data was shown to be conservative

since the specified pressure drop for the QD was higher than the actual Qualification Program data.

Based on the analysis results, Node 1 met the pressure loss requirement for the low-pressure nitrogen distribution.

High-Pressure Nitrogen:

\begin{tabular}{|l|l|c|}
\hline $\begin{array}{c}\text { SSP 41140 } \\
\text { Interface } \\
\text { Parameters }\end{array}$ & \multicolumn{1}{|c|}{$\begin{array}{c}\text { From Node } 3 \text { to } \\
\text { Node } 1\end{array}$} & $\begin{array}{c}\text { To Node } 3 \text { from } \\
\text { Node } 1\end{array}$ \\
\hline Temperature & $\begin{array}{l}25 \text { to } 113^{\circ} \mathrm{F}(-3.9 \text { to } \\
\left.45^{\circ} \mathrm{C}\right)\end{array}$ & N/A \\
\hline Flow Rate & $\leq 3 \mathrm{lbm} / \mathrm{hr}(1.4 \mathrm{~kg} / \mathrm{hr})$ & N/A \\
\hline $\begin{array}{l}\text { Nominal Pressure } \\
\text { Range }\end{array}$ & $\leq 3400 \mathrm{psia}(23.4$ & N/A \\
\hline
\end{tabular}

\begin{tabular}{|l|l|c|}
\hline $\begin{array}{c}\text { SSP 41141 } \\
\text { Interface } \\
\text { Parameters }\end{array}$ & \multicolumn{1}{|c|}{$\begin{array}{c}\text { From U.S. } \\
\text { Laboratory } \\
\text { Module to } \\
\text { Node } 1\end{array}$} & $\begin{array}{c}\text { To U.S. } \\
\text { Laboratory } \\
\text { Module from } \\
\text { Node } 1\end{array}$ \\
\hline Temperature & $\begin{array}{l}25 \text { to } 113^{\circ} \mathrm{F}(-3.9 \text { to } \\
\left.45^{\circ} \mathrm{C}\right)\end{array}$ & N/A \\
\hline Flow Rate & $\leq 3 \mathrm{lbm} / \mathrm{hr}(1.4 \mathrm{~kg} / \mathrm{hr})$ & N/A \\
\hline $\begin{array}{l}\text { Nominal Pressure } \\
\text { Range }\end{array}$ & $\begin{array}{l}\leq 3400 \mathrm{psia}(23.4 \\
\mathrm{MPa})\end{array}$ & $\mathrm{N} / \mathrm{A}$ \\
\hline
\end{tabular}

\begin{tabular}{|l|c|l|}
\hline \multicolumn{1}{|c|}{$\begin{array}{c}\text { SSP 41145 } \\
\text { Interface } \\
\text { Parameters }\end{array}$} & $\begin{array}{c}\text { From Joint } \\
\text { Airlock to } \\
\text { Node } 1\end{array}$ & $\begin{array}{c}\text { To Joint Airlock } \\
\text { from Node } 1\end{array}$ \\
\hline Temperature & $\mathrm{N} / \mathrm{A}$ & $\begin{array}{l}25 \text { to } 113^{\circ} \mathrm{F}(-3.9 \text { to } \\
\left.45^{\circ} \mathrm{C}\right)\end{array}$ \\
\hline Flow Rate & $\mathrm{N} / \mathrm{A}$ & $\leq 3 \mathrm{lbm} / \mathrm{hr}(1.4 \mathrm{~kg} / \mathrm{hr})$ \\
\hline $\begin{array}{l}\text { Nominal Pressure } \\
\text { Range }\end{array}$ & $\mathrm{N} / \mathrm{A}$ & $\begin{array}{l}\leq 3400 \mathrm{psia}(23.4 \\
\mathrm{MPa})\end{array}$ \\
\hline
\end{tabular}

Boeing - Huntington Beach analyzed the pressure loss of the Node 1 high-pressure nitrogen distribution from the Node 1 forward or Node 1 nadir interface to the Node 1 starboard interface at the maximum specified flow rate, temperature, and nominal pressure.

\section{$\underline{\text { Results: }}$}

The calculated pressure loss for the high-pressure nitrogen distribution was $0.02 \mathrm{kPa}$ differential $(0.003$ psid) from the Node 1 nadir interface to the Node 1 starboard interface and was $0.02 \mathrm{kPa}$ differential $(0.003$ psid) from the Node 1 forward interface to the Node 1 starboard interface. The analysis result for this subsystem is considered to be conservative since Boeing - Huntington Beach used the flex hose pressure drop that was recommended by Boeing - Huntsville, which was shown to be conservative when compared to the results from a flex hose development test.

The requirement for this subsystem did not have any pressure loss pass/fail requirement but the value was very low and it was agreed based on that fact that the analysis part of the verification was acceptable.
Pressure Equalization:

\begin{tabular}{|c|c|}
\hline Requirement & Verification \\
\hline $\begin{array}{l}\text { Node } 1 \text { shall when } \\
\text { manually initiated by the } \\
\text { crew internal to the Node } \\
1 \text {, and when not } \\
\text { exchanging atmosphere } \\
\text { with the relevant adjacent } \\
\text { module, provide for } \\
\text { equalization of differential } \\
\text { pressure across the } \\
\text { intermodule hatch } \\
\text { between Node } 1 \text { at } 14.9 \\
\text { psia and an adjacent } \\
\text { vestibule at vacuum to a } \\
\text { maximum differential of } \\
+/-0.01 \text { psi within } 3 \\
\text { minutes. } \\
\text { Note: For purpose of this } \\
\text { requirement Node } 1 \text { is } \\
\text { assumed to be isolated } \\
\text { and the adjacent vestibule } \\
\text { is assumed to have a } \\
\text { volume of } 52 \text { cubic feet. }\end{array}$ & $\begin{array}{l}\text { The Node } 1 \text { equalize pressure } \\
\text { requirement shall be verified by analysis. } \\
\text { The Node } 1 \text { drawings shall be analyzed } \\
\text { to identify the devices that perform the } \\
\text { equalization function. Analysis of the } \\
\text { identified devices shall be performed to } \\
\text { determine the method by which the } \\
\text { equalization is activated. A dynamic gas } \\
\text { flow analysis shall be performed to } \\
\text { determine the rate at which pressure } \\
\text { equalization will occur across the device } \\
\text { between the Node } 1 \text { at } 14.9 \text { psia and an } \\
\text { adjacent vestibule at vacuum. The } \\
\text { analysis shall determine the continuous } \\
\text { pressure differential, as a function of } \\
\text { time, at least until the differential } \\
\text { becomes less than }+/-0.01 \text { psi. } \\
\text { Verification shall be considered } \\
\text { successful when (1) analysis of the Node } \\
1 \text { drawings has identified the devices that } \\
\text { perform the equalization function; ( } 2 \text { ) } \\
\text { analysis of the equalization initiation } \\
\text { methodology confirms it can be } \\
\text { performed by an on-orbit crew inside the } \\
\text { Node } 1, \text { and (3) the gas flow analysis } \\
\text { shows that the differential pressure } \\
\text { between the Node } 1 \text { and an adjacent } \\
\text { vestibule is reduced to } 0.01 \text { psi or less in } \\
3 \text { minutes or less. }\end{array}$ \\
\hline
\end{tabular}

Boeing - Huntington Beach had performed an analysis based on the old pressure equalization requirement. The old version of the requirement required Boeing - Huntington Beach to analyze the equalization of pressure of Node 1 with the relevant adjacent module from a differential pressure of $+/-4.8$ $\mathrm{kPa}(0.7 \mathrm{psi})$ to $+/-0.07 \mathrm{kPa}(0.01 \mathrm{psi})$ within 10 minutes. For this analysis they analyzed two early ingress configurations and two Assembly Complete (AC) configurations. The two early ingress configurations included equalization of Node 1 with PMA 2 or 3 and the Space Shuttle (89.4 cubic meter [3156 cubic feet]) and Node 1 with PMA 1 and the Russian Segment (RS) through Flight 4R (246.1 cubic meter [8689 cubic feet]). While the two $A C$ configurations that they analyzed were the equalization of Node 1 with all of the AC modules forward of Node 1 (481.4 cubic meter [16,997 cubic feet]) and all of the AC modules aft of Node 1 (516.6 cubic meter $[18,241$ cubic feet]).

Boeing - Houston decided to perform the analysis with and without the acoustic muffler attached to the MPEV and assumed the Node 1 with a volume of 51.4 cubic meter (1814.4 cubic feet) and the vestibule on 1.3 cubic meter ( 46.8 cubic feet) based on the new pressure equalization requirement instead of having Boeing Huntington Beach update their analysis. 


\section{Results:}

The calculated pressure equalization time for the old requirement showed that for the early ingress configurations it would take 6.40 minutes to equalize Node 1 with PMA 2/3 and the Space Shuttle and 8.37 minutes to equalize Node 1 with PMA 1 and the 4R RS configuration. For the AC configurations it would take 9.15 minutes to equalize Node 1 with the elements forward of Node 1 and 9.22 minutes to equalize Node 1 with elements aft of Node 1.

The Boeing - Houston analysis calculated that Node 1 would be equalized with the vestibule in 34 seconds without the muffler attached and 118 seconds with the muffler attached. Even though the vestibule volume used in the analysis was smaller than the specified volume the results had so much margin the analysis was not redone with the correct vestibule volume.

Based on the updated analysis results, Node 1 met its pressure equalization requirement.

\section{Node 1 AR QUALIFICATION METHODOLOGY:}

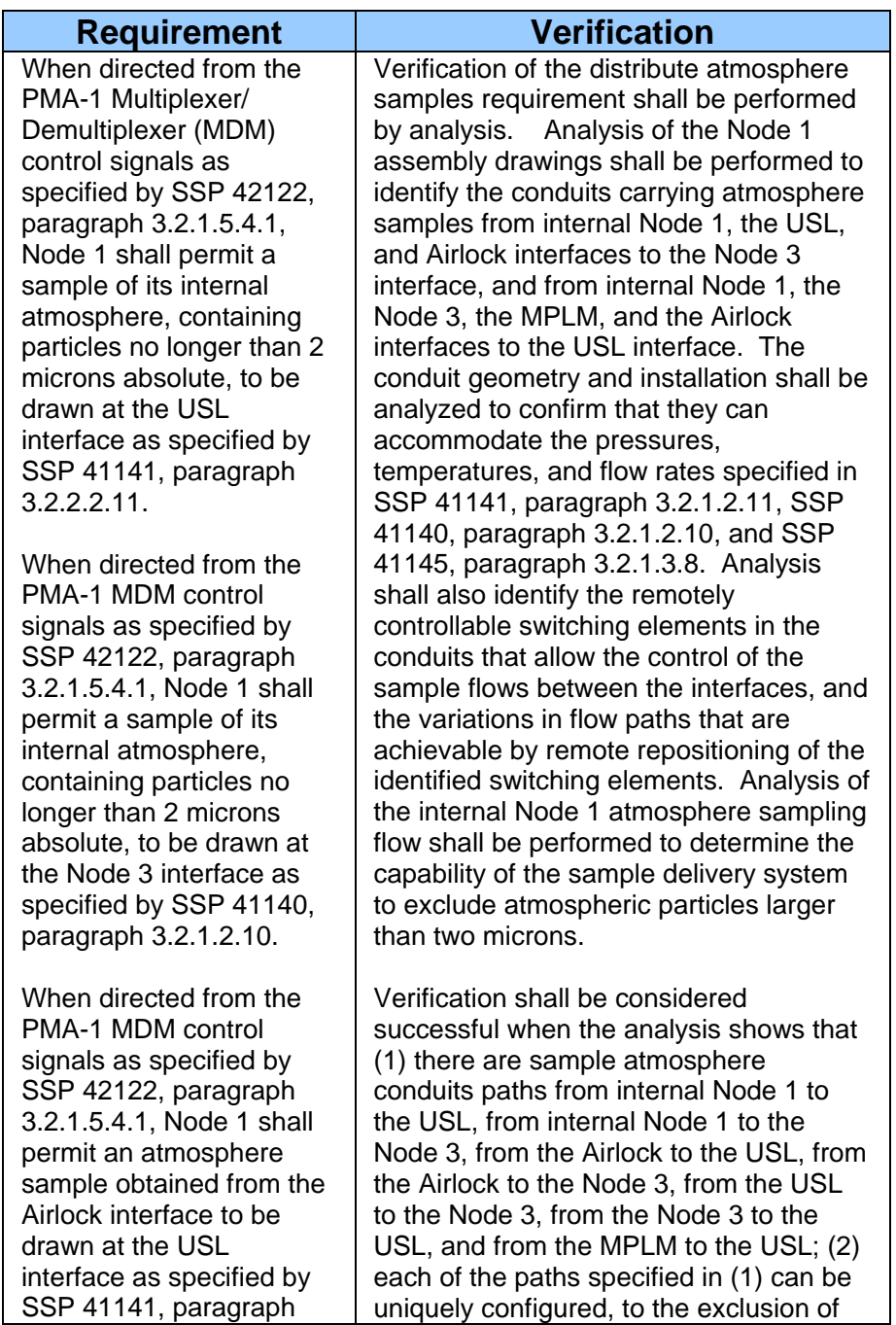

\begin{tabular}{|c|c|}
\hline $\begin{array}{c}\text { Requirement } \\
\text { (cont'd) }\end{array}$ & $\begin{array}{c}\text { Verification } \\
\text { (cont'd) }\end{array}$ \\
\hline 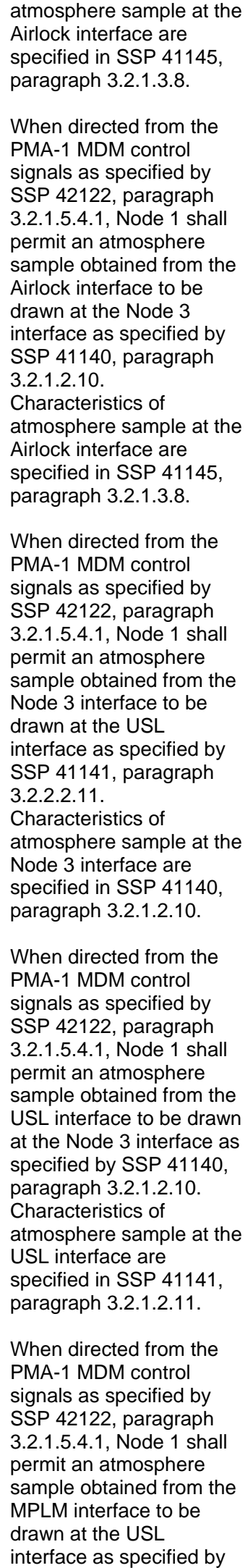 & $\begin{array}{l}\text { elements are remotely controllable by the } \\
\text { discrete PMA-1, N1-MDM interfaces } \\
\text { specified by SSP 42122, paragraph } \\
\text { 3.2.1.5.4.1; (4) the conduits and the } \\
\text { switching elements are sized to } \\
\text { accommodate the range of pressures, } \\
\text { temperatures, and flows specified in SSP } \\
41141 \text {, paragraph } 3.2 .1 .2 .11 \text {, SSP } \\
41140 \text {, paragraph } 3.2 .1 .2 .10 \text {, and SSP } \\
41145 \text {, paragraph } 3.2 .1 .3 .8 \text {, and (5) the } \\
\text { sample delivery system for Node } 1 \\
\text { samples excludes particles larger than } \\
\text { two microns. }\end{array}$ \\
\hline
\end{tabular}




\begin{tabular}{|l|l|}
\hline \multicolumn{1}{|c|}{$\begin{array}{c}\text { Requirement } \\
\text { (cont'd) }\end{array}$} & \multicolumn{1}{|c|}{$\begin{array}{c}\text { Verification } \\
\text { (cont'd) }\end{array}$} \\
\hline $\begin{array}{l}\text { Characteristics of } \\
\text { atmosphere sample at the } \\
\text { MPLM interface are } \\
\text { specified in SSP 42007, } \\
\text { paragraph 3.2.1.3.5. }\end{array}$ \\
\hline
\end{tabular}

Note: The Node 1 element requirement inadvertently did not reference the "To Node 3 from Node 1" (SSP 41140, paragraph 3.2.1.2.15).

The requirement references five ISS ICDs. The relevant requirements from those documents are as follows for the Sample Delivery Subsystem (SDS) distribution:

\begin{tabular}{|l|l|}
\hline $\begin{array}{c}\text { SSP 42122 } \\
\text { Interface Parameters }\end{array}$ & \multicolumn{1}{c|}{$\begin{array}{c}\text { From/To PMA-1 } \\
\text { and Node 1 }\end{array}$} \\
\hline Node 1 ECLS Signals & $\begin{array}{l}\text { The Node 1 shall provide to and receive } \\
\text { from PMA-1 instrumentation signals for } \\
\text { the monitoring and control of the } \\
\text { following ECLSS equipment by the N1-1 } \\
\text { MDM: Atmosphere Revitalization valves, } \\
\text { Smoke Detector, Node 1 Air Mixing } \\
\text { Valve, Cabin Fan, Node 1 Aft IMV Fan, } \\
\text { Node 1 Aft IMV Return and Supply } \\
\text { Valves, Node 1 Starboard Return and } \\
\text { Supply valves, Node 1 Port Supply valve, } \\
\text { Node 1 Rheostat. The interface between } \\
\text { the Node 1 ECLSS equipment and the } \\
\text { N1-1 MDM shall be in compliance with } \\
\text { SSP 30261:002. } \\
\\
\text { The Node 1 shall provide and receive } \\
\\
\text { Trom PMA-1 instrumentation signals for } \\
\\
\text { the monitoring and control of the } \\
\text { following ECLSS equipment by the N1-2 } \\
\text { MDM: Cabin Pressure sensor, Smoke } \\
\text { Detector, Cupola Air Mixing Valve, Node } \\
1 \text { Port and Starboard IMV Fans, Node 1 } \\
\text { Nadir IMV Return and Supply valves, } \\
\text { Node 1 Forward Return and Supply } \\
\text { valves, Cupola Rheostat. The interface } \\
\text { between the Node 1 ECLSS equipment } \\
\text { and the N1-2 MDM shall be in } \\
\text { compliance with SSP 30261:002. }\end{array}$ \\
\hline
\end{tabular}

\begin{tabular}{|c|c|c|}
\hline $\begin{array}{c}\text { SSP 41140 } \\
\text { Interface } \\
\text { Parameters }\end{array}$ & $\begin{array}{c}\text { From Node } 3 \text { to } \\
\text { Node } 1\end{array}$ & $\begin{array}{c}\text { To Node } 3 \text { from } \\
\text { Node } 1\end{array}$ \\
\hline Flow Rate & $100-400 \mathrm{scc} / \mathrm{min}$ & $100-400 \mathrm{scc} / \mathrm{min}$ \\
\hline
\end{tabular}

Note: The Node 1 Pressure Loss requirements for atmosphere samples going to Node 3 were inadvertently deleted when the Program replaced the Habitation Module with Node 3 on Node 1 nadir. The requirements were $\leq 0.40 \mathrm{psid}(2.8 \mathrm{KPa}$ differential) from the Node 1 Sample Probe to Node 3 module interface, $\leq 0.50$ psid $(3.4 \mathrm{KPa}$ differential) from Joint Airlock module interface to Node 3 module interface, and $\leq 0.25 \mathrm{psid}$ (1.7 KPa differential).

\begin{tabular}{|l|l|c|}
\hline $\begin{array}{c}\text { SSP 41141 } \\
\text { Interface } \\
\text { Parameters }\end{array}$ & $\begin{array}{c}\text { From U.S. } \\
\text { Laboratory } \\
\text { Module to } \\
\text { Node } 1\end{array}$ & $\begin{array}{c}\text { To U.S. } \\
\text { Laboratory } \\
\text { Module from } \\
\text { Node 1 }\end{array}$ \\
\hline Flow Rate & $100-400 \mathrm{scc} / \mathrm{min}$ & N/A \\
\hline $\begin{array}{l}\text { Pressure Loss from } \\
\text { Node 1 Sample }\end{array}$ & $\begin{array}{l}\leq 0.4 \mathrm{psid}(2.8 \mathrm{kPa} \\
\text { differential) }\end{array}$ & N/A \\
\hline
\end{tabular}

\begin{tabular}{|l|l|c|}
\hline $\begin{array}{c}\text { SSP 41141 } \\
\text { Interface } \\
\text { Parameters } \\
\text { (cont'd) }\end{array}$ & $\begin{array}{c}\text { From U.S. } \\
\text { Laboratory } \\
\text { Module to } \\
\text { Node 1 } \\
\text { (cont'd) }\end{array}$ & $\begin{array}{c}\text { To U.S. } \\
\text { Laboratory } \\
\text { Module from } \\
\text { Node 1 } \\
\text { (cont'd) }\end{array}$ \\
\hline $\begin{array}{l}\text { Pressure Loss from } \\
\text { Joint Airlock module } \\
\text { interface to USL } \\
\text { module interface }\end{array}$ & $\begin{array}{l}\leq 0.4 \mathrm{psid}(2.8 \mathrm{kPa} \\
\text { differential) }\end{array}$ & N/A \\
\hline $\begin{array}{l}\text { Pressure Loss from } \\
\text { Node 3 or MPLM } \\
\text { module interface to } \\
\text { USL module } \\
\text { interface }\end{array}$ & differential) & N/A \\
\hline
\end{tabular}

\begin{tabular}{|c|c|c|}
\hline $\begin{array}{c}\text { SSP 41145 } \\
\text { Interface } \\
\text { Parameters }\end{array}$ & $\begin{array}{c}\text { From Joint } \\
\text { Airlock to } \\
\text { Node } 1\end{array}$ & $\begin{array}{c}\text { To Joint Airlock } \\
\text { from Node 1 }\end{array}$ \\
\hline Flow Rate & $100-600 \mathrm{scc} / \mathrm{min}$ & N/A \\
\hline
\end{tabular}

\begin{tabular}{|c|c|c|}
\hline $\begin{array}{c}\text { SSP 42007 } \\
\text { Interface } \\
\text { Parameters }\end{array}$ & $\begin{array}{c}\text { From MPLM to } \\
\text { Node } 1\end{array}$ & $\begin{array}{c}\text { To MPLM from } \\
\text { Node } 1\end{array}$ \\
\hline Flow Rate & $100-400 \mathrm{scc} / \mathrm{min}$ & N/A \\
\hline
\end{tabular}

Boeing - Huntington Beach analyzed the pressure loss of the Node 1 AR SDS distribution at $400 \mathrm{scc}$, $29.4^{\circ} \mathrm{C}\left(85^{\circ} \mathrm{F}\right)$, and at a pressure of $101.4 \mathrm{kPa}(14.7$ psia) when transferring air samples to the U.S. Laboratory module or the Node 3 MCA.

\section{$\underline{\text { Results: }}$}

The calculated pressure loss was determined to be $1.8 \mathrm{kPa}$ differential $(0.26 \mathrm{psid})$ from the Node 1 sample probe to the U.S. Laboratory module interface, $2.3 \mathrm{kPa}$ differential $(0.34 \mathrm{psid})$ from the Joint Airlock interface to the U.S. Laboratory module interface, $1.6 \mathrm{kPa}$ differential $(0.23 \mathrm{psid})$ from the Node 3 or MPLM to the U.S. Laboratory module interface, $2.6 \mathrm{kPa}$ differential ( 0.37 psid) from the Node 1 sample probe to the Node 3 module interface, and $3.1 \mathrm{kPa}$ differential ( $0.45 \mathrm{psid}$ ) from the Joint Airlock interface to the Node 3 module interface. The analysis result for this subsystem is satisfactory since Boeing - Huntington Beach used the specified end of life pressure loss for the Node 1 sample probe filter and the specified pressure loss for the manual isolation valves in the analysis. The data used for the Node 1 sample probe filter and the manual isolation valve is considered to be conservative since the sample probe filter supplier and the manual isolation valve supplier went through a Qualification Program to show that the specified pressure drop data was higher when compared to the actual performance of the hardware. As for the flex hoses in the AR SDS distribution Boeing - Huntington Beach used the Boeing - Huntsville recommended pressure drop data, which was shown to be conservative when compared to the results from a flex hose development test. The electrical 
3-way valve Boeing - Huntington Beach used the specified pressure loss data that valve, which was shown during the Qualification Program to have met its specif-

ied pressure loss requirement. The only nonconservative analysis assumption that was used by Boeing - Huntington Beach was the pressure loss for the feed through assembly. Since the data for that component was not available at the time the Node 1 subsystem analysis was being performed by Boeing Huntington Beach they tried to analytically calculate its pressure loss. After the pressure loss data became available for the feed through assembly from the supplier it was obvious that the Boeing - Huntington Beach calculation for the pressure loss under estimated the actual pressure drop for this hardware. If Boeing Huntington Beach had used the feed through assembly Qualification data, i.e. + $0.07 \mathrm{kPa}$ differential (0.01 psid) increase per feed through assembly, without taking advantage of any of the other conservative equipment data the results would have changed to $1.9 \mathrm{kPa}$ differential $(0.27 \mathrm{psid})$ from the Node 1 sample probe to the U.S. Laboratory module interface, $2.5 \mathrm{kPa}$ differential $(0.36 \mathrm{psid})$ from the Joint Airlock interface to the U.S. Laboratory module interface, $1.7 \mathrm{kPa}$ differential $(0.25$ psid) from the Node 3 or MPLM to the U.S. Laboratory module interface, $2.6 \mathrm{kPa}$ differential $(0.38 \mathrm{psid})$ from the Node 1 sample probe to the Node 3 module interface, and $3.2 \mathrm{kPa}$ differential $(0.47 \mathrm{psid})$ from the Joint Airlock interface to the Node 3 module interface.

Based on the analysis results, Node 1 met the pressure loss requirement for the AR SDS distribution.

\section{Node 1 WRM QUALIFICATION METHODOLOGY:}

\section{Fuel Cell Water Distribution:}

\begin{tabular}{|l|l|}
\hline \multicolumn{1}{|c|}{ Requirement } & \multicolumn{1}{c|}{ Verification } \\
\hline $\begin{array}{l}\text { Node 1 shall distribute } \\
\text { fuel cell water from Node } \\
3 \text { to the USL. }\end{array}$ & $\begin{array}{l}\text { The Node 1 distribute fuel cell water } \\
\text { requirement shall be verified by } \\
\text { inspection and analysis. An inspection of } \\
\text { Node 1 drawings shall be performed to } \\
\text { verify the existence of fuel cell water } \\
\text { distribution from the Node 3 to the USL, } \\
\text { cell water from the Node } 3 \\
\text { in accordance with SSP } \\
\text { including interfaces. } \\
\text { 3.2.1.2.9. }\end{array}$ \\
$\begin{array}{l}\text { Node 1 shall supply fuel } \\
\text { cell water to the USL in } \\
\text { accordance with SSP } \\
41141, \text { paragraph }\end{array}$ & $\begin{array}{l}\text { distribution shall be performed to } \\
\text { determine the pressure loss } \\
\text { characteristics considering the } \\
\text { temperature, pressure, and flow rate } \\
\text { specified in SSP 41140, paragraph }\end{array}$ \\
& $\begin{array}{l}\text { 3.2.1.2.9, and under the environmental } \\
\text { conditions specified in 3.2.5.1.5. An } \\
\text { analysis shall also consider the proximity } \\
\text { of thermal sources to the location of the } \\
\text { fuel cell water distribution to verify that } \\
\text { the temperature is maintained as } \\
\text { specified in the ICD. }\end{array}$ \\
& $\begin{array}{l}\text { The verification shall be considered } \\
\text { successful when the inspection identifies } \\
\text { fuel cell water distribution from the Node }\end{array}$ \\
\hline
\end{tabular}

\begin{tabular}{|l|l|}
\hline $\begin{array}{c}\text { Requirement } \\
\text { (cont'd) }\end{array}$ & \multicolumn{1}{c|}{$\begin{array}{c}\text { Verification } \\
\text { (cont'd) }\end{array}$} \\
\hline & $\begin{array}{l}\text { successful when (1) given the ICD } \\
\text { temperature, pressure, and flow rate, the } \\
\text { resulting pressure loss in Node } 1 \text { is as } \\
\text { specified in the ICD, and (2) given the } \\
\text { input temperature ranges in the ICD and } \\
\text { the distribution location in Node 1, that } \\
\text { the outlet temperature range is } \\
\text { maintained as specified in the ICD. }\end{array}$ \\
\hline
\end{tabular}

Note: The Node 1 element requirement inadvertently did not reference the "To Node 3 from Node 1" (SSP 41140, paragraph 3.2.1.2.11) and the "From U.S. Laboratory Module to Node 1" (SSP 41141, paragraph 3.2.1.2.15) ICD requirements.

The requirement references two ISS ICDs. The relevant requirements from those documents are as follows:

\begin{tabular}{|l|l|l|}
\hline $\begin{array}{c}\text { SSP 41140 } \\
\text { Interface } \\
\text { Parameters }\end{array}$ & \multicolumn{1}{|c|}{$\begin{array}{c}\text { From Node 3 } \\
\text { To Node } 1\end{array}$} & $\begin{array}{l}\text { To Node } 3 \text { from } \\
\text { Node } 1\end{array}$ \\
\hline Temperature & $\begin{array}{l}65 \text { to } 113^{\circ} \mathrm{F}(18.3 \text { to } \\
\left.45^{\circ} \mathrm{C}\right)\end{array}$ & $\begin{array}{l}65 \text { to } 113^{\circ} \mathrm{F}(18.3 \text { to } \\
\left.45^{\circ} \mathrm{C}\right)\end{array}$ \\
\hline Pressure Drop & \multicolumn{1}{|c|}{$\mathrm{N} / \mathrm{A}$} & $\begin{array}{l}\leq 0.6 \mathrm{psid}(4.1 \mathrm{kPa} \\
\text { differential) } \text { at } 240 \\
\text { lbm/hr }(108.8 \mathrm{~kg} / \mathrm{hr}) \\
\text { from USL }\end{array}$ \\
& & $\begin{array}{l}35 \mathrm{psig}(241.3 \mathrm{kPa} \\
\text { gauge })\end{array}$ \\
\hline Maximum Pressure & $\begin{array}{l}35 \mathrm{psig}(241.3 \mathrm{kPa} \\
\text { gauge })\end{array}$ \\
\hline
\end{tabular}

\begin{tabular}{|c|c|c|}
\hline $\begin{array}{l}\text { SSP } 41141 \\
\text { Interface } \\
\text { Parameters }\end{array}$ & $\begin{array}{l}\text { From U.S. } \\
\text { Laboratory } \\
\text { Module to } \\
\text { Node } 1\end{array}$ & $\begin{array}{l}\text { To U.S. } \\
\text { Laboratory } \\
\text { Module from } \\
\text { Node } 1\end{array}$ \\
\hline Temperature & $\begin{array}{l}65 \text { to } 113^{\circ} \mathrm{F}(18.3 \text { to } \\
\left.45^{\circ} \mathrm{C}\right)\end{array}$ & $\begin{array}{l}65 \text { to } 113^{\circ} \mathrm{F}(18.3 \text { to } \\
\left.45^{\circ} \mathrm{C}\right)\end{array}$ \\
\hline $\begin{array}{l}\text { Fuel Cell Water Free } \\
\text { Gas Quality }\end{array}$ & N/A & $\begin{array}{l}\leq 10 \% \text { peak by } \\
\text { volume at } 40^{\circ} \mathrm{F}(4.4 \\
\left.{ }^{\circ} \mathrm{C}\right) \text { and } 20.7 \mathrm{psia} \\
(142.7 \mathrm{kPa})\end{array}$ \\
\hline Maximum Pressure & $\begin{array}{l}35 \mathrm{psig}(241.3 \mathrm{kPa} \\
\text { gauge) }\end{array}$ & $\begin{array}{l}35 \mathrm{psig}(241.3 \mathrm{kPa} \\
\text { gauge) }\end{array}$ \\
\hline
\end{tabular}

Boeing - Huntington Beach analyzed the pressure loss of the Node 1 Fuel Cell Water distribution at 108.8 $\mathrm{kg} / \mathrm{hr}(240 \mathrm{lbm} / \mathrm{hr})$ and a maximum specified temperature at an initial pressure of $142.7 \mathrm{kPa}$ gauge (20.7 psig) when transferring Fuel Cell Water between the U.S. Laboratory Module and Node 3.

Since the original verification analysis was completed the ISS ECLS interfaces requirements were changed to allow the use of the Fuel Cell Water distribution to distribute potable water from the Regenerative ECLS WPA to users outside of Node 3 . Based on this change the pressure loss requirement was reduced from $\leq 6.9$ $\mathrm{kPa}$ ( $1 \mathrm{psid})$ to $\leq 4.1 \mathrm{kPa}(0.6 \mathrm{psid})$ and the maximum pressure was increased from $142.7 \mathrm{kPa}$ gauge (20.7 
psig) to $241.3 \mathrm{kPa}$ (35 psig). These changes had no impact on the Boeing - Huntington Beach analysis. accordance with SSP

41141, paragraph

3.2.1.2.9. distribution location in Node 1 , that the outlet temperature range is

maintained as specified in the ICD.

\section{$\underline{\text { Results: }}$}

The calculated pressure loss was determined to be $3.9 \mathrm{kPa}$ differential (0.56 psid). The analysis result for this subsystem is very conservative since Boeing Huntington Beach used the flex hose and the QD specified pressure drop data in the analysis. The analysis is considered to be conservative because the flex hose supplier performed a development test and the QD supplier went through a Qualification Program to show that the specified pressure drop data was higher when compared to the actual performance of the hardware.

Based on the analysis results, Node 1 met the pressure loss requirement for the Fuel Cell Water distribution.

The inspection memorandum also showed that the drawings called out in the memorandum met the inspection part of the Verification.

\section{Waste Water Distribution:}

\begin{tabular}{|c|c|}
\hline Requirement & Verification \\
\hline $\begin{array}{l}\text { Node } 1 \text { shall distribute } \\
\text { waste water from the USL } \\
\text { to the Node } 3 . \\
\text { Node } 1 \text { shall distribute } \\
\text { waste water from the } \\
\text { Node } 3 \text { to the USL. } \\
\text { Node } 1 \text { shall distribute } \\
\text { waste water from the } \\
\text { Airlock to the USL. }\end{array}$ & $\begin{array}{l}\text { The Node } 1 \text { distribute waste water } \\
\text { requirement shall be verified by } \\
\text { inspection and analysis. An inspection of } \\
\text { Node } 1 \text { drawings shall be performed to } \\
\text { verify the existence of waste water } \\
\text { distribution as follows: (1) USL interface } \\
\text { to Node } 3 \text { interface, (2) Node } 3 \text { interface } \\
\text { to USL interface, (3) Airlock interface to } \\
\text { USL interface, and (4) Airlock interface to } \\
\text { Node } 3 \text { interface. } \\
\text { An analysis of the waste water } \\
\text { distribution shall be performed to } \\
\text { determine the pressure loss } \\
\text { characteristics considering the } \\
\text { temperature, pressure, and flow rate } \\
\text { specified in the ICDs. An analysis shall } \\
\text { also consider the proximity of thermal } \\
\text { sources to the location of the waste water } \\
\text { distribution to verify that the temperature } \\
\text { is maintained as specified in the ICD. }\end{array}$ \\
\hline $\begin{array}{l}\text { Node } 1 \text { shall receive } \\
\text { return waste water from } \\
\text { the Node } 3 \text { in accordance } \\
\text { with SSP } 41140 \text {, } \\
\text { paragraph 3.2.1.2.14. } \\
\text { Node } 1 \text { shall deliver return } \\
\text { waste water to the USL in }\end{array}$ & $\begin{array}{l}\text { The verification shall be considered } \\
\text { successful when the inspection identifies } \\
\text { waste water distribution as follows: (1) } \\
\text { USL interface to Node } 3 \text { interface, (2) } \\
\text { Node } 3 \text { interface to USL interface, ( } 3 \text { ) } \\
\text { Airlock interface to USL interface, and (4) } \\
\text { Airlock interface to Node } 3 \text { interface. } \\
\text { The analysis will be considered } \\
\text { successful when, (1) given the ICD } \\
\text { temperature, pressure, and flow rate, the } \\
\text { resulting pressure loss in Node } 1 \text { is as } \\
\text { specified in the ICD, and (2) given the } \\
\text { input temperature ranges in the ICD and }\end{array}$ \\
\hline
\end{tabular}

\begin{tabular}{|l|l|}
\hline \multicolumn{1}{|c|}{$\begin{array}{c}\text { Requirement } \\
\text { (cont'd) }\end{array}$} & \multicolumn{1}{|c|}{$\begin{array}{c}\text { Verification } \\
\text { (cont'd) }\end{array}$} \\
\hline Node 1 shall receive & \\
waste water from the & \\
Airlock in accordance with & \\
SSP 41145, paragraph & \\
3.2.1.3.7. & \\
\hline
\end{tabular}

The requirement references three ISS ICDs. The relevant requirements from those documents are as follows:

\begin{tabular}{|c|c|c|}
\hline $\begin{array}{l}\text { SSP } 41140 \\
\text { Interface } \\
\text { Parameters }\end{array}$ & $\begin{array}{c}\text { From Node } 3 \\
\text { To Node } 1\end{array}$ & $\begin{array}{c}\text { To Node } 3 \text { from } \\
\text { Node } 1\end{array}$ \\
\hline $\begin{array}{l}\text { Temperature at } \\
\text { Nominal Flow Rate }\end{array}$ & $\begin{array}{l}55 \text { to } 113^{\circ} \mathrm{F}(12.8 \text { to } \\
\left.45^{\circ} \mathrm{C}\right)\end{array}$ & $\begin{array}{l}55 \text { to } 113^{\circ} \mathrm{F}(12.8 \text { to } \\
\left.45^{\circ} \mathrm{C}\right)\end{array}$ \\
\hline $\begin{array}{l}\text { Temperature at } \\
\text { Maximum Flow Rate }\end{array}$ & $\mathrm{N} / \mathrm{A}$ & $\begin{array}{l}55 \text { to } 113^{\circ} \mathrm{F}(12.8 \text { to } \\
\left.45^{\circ} \mathrm{C}\right)\end{array}$ \\
\hline $\begin{array}{l}\text { Temperature at } \\
\text { Transient Flow Rate }\end{array}$ & $\begin{array}{l}40 \text { to } 113^{\circ} \mathrm{F}(4.4 \text { To } \\
\left.45^{\circ} \mathrm{C}\right)\end{array}$ & $\begin{array}{l}33 \text { to } 113^{\circ} \mathrm{F}(0.6 \text { To } \\
\left.45^{\circ} \mathrm{C}\right)\end{array}$ \\
\hline $\begin{array}{l}\text { Waste Water Free } \\
\text { Gas Water Quality }\end{array}$ & $\begin{array}{l}\leq 10 \% \text { peak by } \\
\text { volume at } 40^{\circ} \mathrm{F}(4.4 \\
\left.{ }^{\circ} \mathrm{C}\right) \text { and } 20.7 \mathrm{psia} \\
(142.7 \mathrm{kPa})\end{array}$ & $\begin{array}{l}\leq 10 \% \text { peak by } \\
\text { volume at } 40^{\circ} \mathrm{F}(4.4 \\
\left.{ }^{\circ} \mathrm{C}\right) \text { and } 20.7 \text { psia } \\
(142.7 \mathrm{kPa})\end{array}$ \\
\hline $\begin{array}{l}\text { Waste Water } \\
\text { Particulate Level }\end{array}$ & $\leq 100$ microns & $\leq 100$ microns \\
\hline Nominal Flow Rate & $\begin{array}{l}0 \text { to } 2 \mathrm{lbm} / \mathrm{hr} \text { (0 to } 0.9 \\
\mathrm{~kg} / \mathrm{hr} \text { ) }\end{array}$ & $\begin{array}{l}0 \text { to } 2 \mathrm{lbm} / \mathrm{hr} \text { (0 to } 0.9 \\
\mathrm{~kg} / \mathrm{hr} \text { ) }\end{array}$ \\
\hline Maximum Flow Rate & $\mathrm{N} / \mathrm{A}$ & $\begin{array}{l}0 \text { to } 65 \mathrm{lbm} / \mathrm{hr} \text { (0 to } \\
29.5 \mathrm{~kg} / \mathrm{hr} \text { ) }\end{array}$ \\
\hline
\end{tabular}

\begin{tabular}{|c|c|c|}
\hline $\begin{array}{l}\text { SSP } 41140 \\
\text { Interface } \\
\text { Parameters } \\
\text { (cont'd) }\end{array}$ & $\begin{array}{l}\text { From Node } 3 \\
\text { To Node } 1 \\
\text { (cont'd) }\end{array}$ & $\begin{array}{l}\text { To Node } 3 \text { from } \\
\text { Node } 1 \\
\text { (cont'd) }\end{array}$ \\
\hline Transient Flow Rate & $\begin{array}{l}0 \text { to } 132.0 \mathrm{lbm} / \mathrm{hr}(0 \\
\text { to } 59.9 \mathrm{~kg} / \mathrm{hr})\end{array}$ & $\begin{array}{l}0 \text { to } 132.0 \mathrm{lbm} / \mathrm{hr}(0 \\
\text { to } 59.9 \mathrm{~kg} / \mathrm{hr})\end{array}$ \\
\hline Pressure Drop & N/A & $\begin{array}{l}\leq 1 \mathrm{psid}(<6.9 \mathrm{kPa} \\
\text { differential) at } \\
\text { transient flow rate } \\
\text { from Airlock or USL }\end{array}$ \\
\hline Nominal Pressure & $\begin{array}{l}0 \text { to } 8 \text { psig ( } 0 \text { to } 55.2 \\
\mathrm{kPa} \text { gauge) }\end{array}$ & $\begin{array}{l}0 \text { to } 8 \text { psig (0 to } 55.2 \\
\mathrm{kPa} \text { gauge) }\end{array}$ \\
\hline Maximum Pressure & $\begin{array}{l}85 \text { psig (586.1 kPa } \\
\text { gauge) }\end{array}$ & $\begin{array}{l}85 \text { psig }(586.1 \mathrm{kPa} \\
\text { gauge) }\end{array}$ \\
\hline
\end{tabular}

\begin{tabular}{|l|l|l|}
\hline $\begin{array}{c}\text { SSP 41141 } \\
\text { Interface } \\
\text { Parameters }\end{array}$ & \multicolumn{1}{|c|}{$\begin{array}{c}\text { From U.S. } \\
\text { Laboratory } \\
\text { Module to } \\
\text { Node } 1\end{array}$} & $\begin{array}{c}\text { To U.S. } \\
\text { Laboratory } \\
\text { Module from } \\
\text { Node } 1\end{array}$ \\
\hline $\begin{array}{l}\text { Temperature at } \\
\text { Nominal Flow Rate }\end{array}$ & $\begin{array}{l}55 \text { to } 113^{\circ} \mathrm{F}(12.8 \text { to } \\
\left.45^{\circ} \mathrm{C}\right)\end{array}$ & $\begin{array}{l}55 \text { to } 113^{\circ} \mathrm{F}(12.8 \text { to } \\
\left.45^{\circ} \mathrm{C}\right)\end{array}$ \\
\hline $\begin{array}{l}\text { Temperature at } \\
\text { Transient Flow Rate }\end{array}$ & $\begin{array}{l}55 \text { to } 113^{\circ} \mathrm{F}(12.8 \text { to } \\
\left.45^{\circ} \mathrm{C}\right)\end{array}$ & $\begin{array}{l}40 \text { to } 113^{\circ} \mathrm{F}(4.4 \text { to } \\
\left.45^{\circ} \mathrm{C}\right)\end{array}$ \\
\hline $\begin{array}{l}\text { Waste Water Free } \\
\text { Gas Water Quality }\end{array}$ & $\begin{array}{l}\leq 10 \% \text { peak by } \\
\text { volume at } 40^{\circ} \mathrm{F}(4.4\end{array}$ & \multicolumn{1}{|c|}{$\mathrm{N} / \mathrm{A}$} \\
& $\begin{array}{l}\left.{ }^{\circ} \mathrm{C}\right) \text { and } 20.7 \text { psia } \\
(142.7 \mathrm{kPa})\end{array}$ & \\
\hline
\end{tabular}




\begin{tabular}{|l|c|l|}
\hline $\begin{array}{l}\text { Waste Water } \\
\text { Particulate Level }\end{array}$ & $\leq 100$ microns & \multicolumn{1}{|c|}{ N/A } \\
\hline Nominal Flow Rate & $\leq 2 \mathrm{lbm} / \mathrm{hr}(0.9 \mathrm{~kg} / \mathrm{hr})$ & $\leq 2 \mathrm{lbm} / \mathrm{hr}(0.9 \mathrm{~kg} / \mathrm{hr})$ \\
\hline Maximum Flow Rate & N/A & $\begin{array}{l}0 \text { to } 65 \mathrm{lbm} / \mathrm{hr}(0 \text { to } \\
29.5 \mathrm{~kg} / \mathrm{hr})\end{array}$ \\
\hline
\end{tabular}

\begin{tabular}{|c|c|c|}
\hline $\begin{array}{l}\text { SSP } 41141 \\
\text { Interface } \\
\text { Parameters } \\
\text { (cont'd) }\end{array}$ & $\begin{array}{l}\text { From U.S. } \\
\text { Laboratory } \\
\text { Module to } \\
\text { Node } 1 \\
\text { (cont'd) }\end{array}$ & $\begin{array}{l}\text { To U.S. } \\
\text { Laboratory } \\
\text { Module from } \\
\text { Node } 1 \\
\text { (cont'd) }\end{array}$ \\
\hline Transient Flow Rate & $\begin{array}{l}0 \text { to } 132.0 \mathrm{lbm} / \mathrm{hr}(0 \\
\text { to } 59.9 \mathrm{~kg} / \mathrm{hr})\end{array}$ & $\begin{array}{l}0 \text { to } 132.0 \mathrm{lbm} / \mathrm{hr}(0 \\
\text { to } 59.9 \mathrm{~kg} / \mathrm{hr})\end{array}$ \\
\hline Pressure Drop & N/A & $\begin{array}{l}\leq 1 \mathrm{psid}(<6.9 \mathrm{kPa} \\
\text { differential) at } \\
\text { transient flow rate } \\
\text { from Airlock or Node } \\
3\end{array}$ \\
\hline Nominal Pressure & $\begin{array}{l}0 \text { to } 8 \text { psig ( } 0 \text { to } 55.2 \\
\mathrm{kPa} \text { gauge) }\end{array}$ & $\begin{array}{l}0 \text { to } 8 \text { psig ( } 0 \text { to } 55.2 \\
\mathrm{kPa} \text { gauge) }\end{array}$ \\
\hline Maximum Pressure & $\begin{array}{l}85 \text { psig }(586.1 \mathrm{kPa} \\
\text { gauge) }\end{array}$ & $\begin{array}{l}85 \text { psig }(586.1 \mathrm{kPa} \\
\text { gauge) }\end{array}$ \\
\hline
\end{tabular}

\begin{tabular}{|c|c|c|}
\hline $\begin{array}{l}\text { SSP } 41145 \\
\text { Interface } \\
\text { Parameters }\end{array}$ & $\begin{array}{l}\text { From Joint } \\
\text { Airlock to } \\
\text { Node } 1\end{array}$ & $\begin{array}{l}\text { To Joint Airlock } \\
\text { from Node } 1\end{array}$ \\
\hline $\begin{array}{l}\text { Temperature at } \\
\text { Nominal Flow Rate }\end{array}$ & $\begin{array}{l}55 \text { to } 113^{\circ} \mathrm{F}(12.8 \text { to } \\
\left.45^{\circ} \mathrm{C}\right)\end{array}$ & $\mathrm{N} / \mathrm{A}$ \\
\hline $\begin{array}{l}\text { Temperature at } \\
\text { Transient Flow Rate }\end{array}$ & $\begin{array}{l}40 \text { to } 113^{\circ} \mathrm{F}(4.4 \text { to } \\
\left.45^{\circ} \mathrm{C}\right)\end{array}$ & $\mathrm{N} / \mathrm{A}$ \\
\hline $\begin{array}{l}\text { Waste Water Free } \\
\text { Gas Water Quality }\end{array}$ & $\begin{array}{l}\leq 10 \% \text { peak by } \\
\text { volume at } 40^{\circ} \mathrm{F}(4.4 \\
\left.{ }^{\circ} \mathrm{C}\right) \text { and } 20.7 \mathrm{psia} \\
(142.7 \mathrm{kPa})\end{array}$ & N/A \\
\hline $\begin{array}{l}\text { Waste Water } \\
\text { Particulate Level }\end{array}$ & $\leq 100$ microns & N/A \\
\hline Nominal Flow Rate & $\begin{array}{l}0-0.5 \mathrm{lbm} / \mathrm{hr}(0- \\
0.23 \mathrm{~kg} / \mathrm{hr})\end{array}$ & $\mathrm{N} / \mathrm{A}$ \\
\hline Maximum Flow Rate & $\begin{array}{l}\leq 65 \mathrm{lbm} / \mathrm{hr}(29.5 \\
\mathrm{kg} / \mathrm{hr})\end{array}$ & $\mathrm{N} / \mathrm{A}$ \\
\hline Transient Flow Rate & $\begin{array}{l}0 \text { to } 80 \mathrm{lbm} / \mathrm{hr} \text { (0 to } \\
36.3 \mathrm{~kg} / \mathrm{hr} \text { ) }\end{array}$ & $\mathrm{N} / \mathrm{A}$ \\
\hline Pressure Drop & $\mathrm{N} / \mathrm{A}$ & N/A \\
\hline Nominal Pressure & $\begin{array}{l}0 \text { to } 8 \text { psig ( } 0 \text { to } 55.2 \\
\mathrm{KPa} \text { gauge) }\end{array}$ & $\mathrm{N} / \mathrm{A}$ \\
\hline Maximum Pressure & $\begin{array}{l}85 \text { psig (586.1 kPa } \\
\text { gauge) }\end{array}$ & $\mathrm{N} / \mathrm{A}$ \\
\hline
\end{tabular}

Boeing - Huntington Beach analyzed the pressure loss of the Node 1 Waste Water distribution at $59.9 \mathrm{~kg} / \mathrm{hr}$ $(132 \mathrm{lbm} / \mathrm{hr})$ and a maximum specified temperature at an initial pressure of $55.2 \mathrm{kPa}$ gauge (8 psig) when transporting Waste Water between the required interfaces.

\section{Results:}

The calculated pressure loss for the Waste Water lines was determined to be $0.76 \mathrm{kPa}$ differential $(0.11$ psid) from Joint Airlock interface to the U.S. Laboratory Module interface, 0.24 psid (1.65 kPa differential) from Joint Airlock interface to the Node 3 interface, and 1.38 $\mathrm{kPa}$ differential (0.20 psid) between the U.S. Laboratory Module and Node 3 interfaces. The analysis result for this subsystem is very conservative since Boeing Huntington Beach used the flex hose and the QD specified pressure drop data in the analysis. The analysis is considered to be conservative because the flex hose supplier performed a development test and the QD supplier went through a Qualification Program to show that the specified pressure drop data was higher

when compared to the actual performance of the hardware.

Based on the analysis results, Node 1 met the pressure loss requirement for the Waste Water distribution.

The inspection memorandum also showed that the drawings called out in the memorandum met the inspection part of the Verification.

\section{CONCLUSION}

The Verification of Node 1 utilized a building block approach from the Component Qualification data through to the Element Level Verification. This paper provides a general overview of the nominal operation of the ACS, AR, and WRM subsystems in Node 1 and of the ISS ECLS Element Level Verification program for these subsystems in Node 1 . It also showed that nominal operation of the Node 1 subsystems discussed in this paper met all of their Element Level requirements.

\section{REFERENCES}

1. "Prime Item Development Specification for Node 1"; S684-10102, Revision J; November 20, 2002.

2. "Space Station Program Node Element 1 to Node Element 3 Interface Control Document, Part 1"; SSP 41140, Revision E; August 24, 2005.

3. "Node 1 Element to U.S. Laboratory Element Interface Control Document, Part 1"; SSP 41141, Revision F; December 10, 2004.

4. "Node 1 Element to Airlock Element Interface Control Document, Part 1"; SSP 41145, Revision E plus IRN 41145-0074A; January 5, 2002.

5. "United States On-Orbit Segment to Italian Mini Pressurized Logistics Module Interface Control Document, Part 1"; SSP 42007, Revision H; December 31, 2002.

6. "Resource Node 1 to Pressurized Mating Adapter-1 Interface Control Document, Part 1"; SSP 42122, Revision D plus IRN 0019, 0016, and 0020; December 20, 2002.

7. Boeing - Huntington Beach; "International Space Station Node 1 Pressure Monitoring and Equalization ECLSS Verification Analysis Report”; MDC 96H0634B; February 13, 1988. 
8. Boeing - Huntington Beach; "International Space Station Node 1 Atmosphere Sample Distribution Pressure Loss ECLSS Verification Analysis Report"; MDC 97H0372C; February 13, 1988.

9. Boeing - Huntington Beach; "International Space Station Node 1 Atmosphere Control System Distribution Pressure Loss ECLSS Verification Analysis Report"; MDC 97H0374C; January $30,1988$.

10. Boeing - Huntington Beach; "International Space Station Node 1 Water Recovery Management Pressure Loss ECLSS Verification Analysis Report"; MDC 97H0375B; January 30, 1988.

11. "ISS Node 1 Fuel Cell and Waste Water Distribution Inspection Verification" Memorandum; A3-J011-LE-M-9800431; March 12, 1998.

12. Erwin, Lowell; email titled "Data"; April 3, 1998.

13. "Pressure Equalization of Vestibule with Node 1" Memorandum; 2-6920-ECLS-CHS-98-033; August 11, 1998.

\section{CONTACT}

David E. Williams

NASA, Lyndon B. Johnson Space Center /

Mail Stop: EC6

2101 NASA Parkway

Houston, TX 77058

\section{ACRONYMS}

${ }^{\circ} \mathrm{C}: \quad$ degree celsius

${ }^{\circ} \mathrm{F}$ : degree fahrenheit

AC: Assembly Complete

ACS: Atmosphere Control and Supply

AR: Atmosphere Revitalization

DPA: Depressurization Pump Assembly

ECLS: Environmental Control and Life Support

EVA: Extravehicular Activity

FDS: Fire Detection and Suppression

hr: hour

ICD: Interface Control Document

IMV: Intermodule Ventilation

in: inch

ISS: International Space Station

kg: kilogram

$\mathrm{kPa}$ : kilopascal

KSC: Kennedy Space Center

$\mathrm{lbm}$ : pound mass

MCA: Major Constituent Analyzer

MDM: Multiplexer/Demultiplexer

min: minute

MPa: megapascal
MPEV: Manual Pressure Equalization Valve MPLM: Multi-Purpose Logistic Module or MiniPressurized Logistic Module

PIDS: Prime Item Development Specification PMA: Pressurized Mating Adapter ppCH4: partial pressure of methane ppCO2: partial pressure of carbon dioxide $\mathrm{ppH}$ 2: partial pressure of hydrogen $\mathrm{ppH} 2 \mathrm{O}$ : partial pressure of water vapor ppO2: partial pressure of oxygen ppN2: partial pressure of nitrogen psi: $\quad$ pounds per square inch

psia: pounds per square inch absolute psid: pounds per square inch differential psig: pounds per square inch gauge

QD: Quick Disconnect

RS: Russian Segment

scc: $\quad$ standard cubic centimeter

SDS: Sample Delivery Subsystem

SSP: $\quad$ Space Station Program

THC: Temperature and Humidity Control

U.S.: United States

USL: United States Laboratory

USOS: United States On-Orbit Segment

WPA: Water Processor Assembly

WRM: Water Recovery and Management 